\title{
9. MIOCENE THROUGH QUATERNARY PLANKTONIC FORAMINIFERS FROM OFFSHORE SOUTHERN CALIFORNIA AND BAJA CALIFORNIA ${ }^{1}$
}

\author{
Richard Z. Poore, U.S. Geological Survey, Menlo Park, California
}

\begin{abstract}
Eleven holes were drilled at seven sites off southern California and Baja California during Deep Sea Drilling Project Leg 63. Planktonic foraminifers are few to abundant in Pliocene and Quaternary sediments and essentially absent from pre-Pliocene sediments recovered from three sites (Sites 467-469) in the California Continental Borderland. Planktonic foraminifers are present but sparse throughout the middle Miocene through Quaternary sequence recovered at Site 470 near Guadalupe Island. Pliocene planktonic foraminiferal assemblages from these four northern sites indicate that poleward migration of warm surface waters occurred at about 4.0 and 2.8 m.y. ago. Extratropical late Cenozoic North Pacific and North Atlantic planktonic foraminifer datum events are compared and correlated.

Subtropical planktonic foraminiferal assemblages recovered at Sites 471 through $\mathbf{4 7 3}$ are generally sparse and show effects of dissolution.
\end{abstract}

\section{INTRODUCTION}

DSDP Leg 63 started in Long Beach, California, on October 9, 1978, and ended in Mazatlan, Mexico, on November 26. Eleven holes were drilled at seven sites during Leg 63 (Table 1; Fig. 1).

Sites 467 through 469 are in or adjacent to the California Continental Borderland. Planktonic foraminifers are generally few to abundant in Pliocene and Quaternary sediments recovered from the borderland and sparse or absent in pre-Pliocene sediments. Evidence of reworking was seen at all three borderland sites.

Site 470 is east of Guadalupe Island, Mexico, near the Experimental Mohole Site drilled in 1961. Planktonic foraminifers are present in low abundance throughout the middle Miocene through Quaternary sequence recovered there.

Subtropical Pliocene and Quaternary planktonic foraminiferal assemblages were recovered from sediments of offshore Baja California Sites 471 and 473, whereas sparse subtropical middle Miocene assemblages were found at Site 472 .

Tables 2 through 10 show abundance estimates of planktonic foraminifers and other selected constituents of samples examined for this report. After dispersing a more or less uniform amount of processed material ( $\geq 149$-mm-size fraction) on a standard 60 -square micropaleontologic slide, abundances were estimated as follows: Species occurring several times per square were tabulated as abundant, those occurring about once per square were tabulated as common, and those occurring once per several squares were tabulated as few. Taxa requiring a more intensive search or found only in the $\leq 149$-mm-size fraction were tabulated as sparse. To aid age assignments and comparisons of the results of Leg 63 with other studies, I have interpreted the planktonic

\footnotetext{
${ }^{1}$ Initial Reports of the Deep Sea Drilling Project, Volume 63.
}

foraminiferal assemblages in Leg 63 samples in terms of the standard zonation of Blow (1969). Primary zonal indicators are absent or sparse at most localities sampled during Leg 63. Most zone assignments are therefore based on secondary indicators, and zone boundaries shown on figures and tables represent approximations.

Following presentation and general explanation of planktonic foraminiferal occurrences in all Leg 63 sites, the biostratigraphic and paleoclimatic implications of Pliocene and Quaternary assemblages of Sites 467 through 470 are discussed in more detail.

Original designations of taxa identified during this study, as well as comments for selected taxa, are provided in the Taxonomic Notes.

\section{SITE 467}

Site 467 is in the San Miguel Gap area of the outer California Continental Borderland (Fig. 1). Hole 467 was continuously cored to a sub-bottom depth of $1,041.5$ meters. Planktonic foraminifers are common to abundant in Cores 1 through 18 and common to sparse in Cores 19 through 33. Sediments recovered below Core 33 (307 m sub-bottom) are essentially barren of planktonic foraminifers.

Assemblages in Cores 33 through 27 (Table 2) are only diagnostic of upper Miocene to lower Pliocene Zones N17 through N19. Coccoliths and siliceous microfossils from this interval are more definitive and suggest a lower Pliocene assignment. The occurrence of Globorotalia crassaformis and Globigerina umbilicata in samples from Cores 26 and $\mathbf{2 5}$ indicates a Pliocene Zone N19 to N21 assignment; the last occurrences of Sphaeroidinellopsis spp., Globigerina woodi, and Neogloboquadrina acostaensis in or just below Sample $467-25-4,60-62 \mathrm{~cm}$ are used to approximate the upper limit of Zone N19. Note that typical or modern representatives of Neogloboquadrina pachyderma first occur in Sample 467-21-1, 26-28 cm. Previous work in the Atlantic basin (Poore and Berggren, 1975; Poore, 1979) suggests that the first occurrence of Neogloboquadrina 
Table 1. Location and coring summary for Leg 63 sites.

\begin{tabular}{|c|c|c|c|c|c|c|c|c|c|}
\hline Hole & $\begin{array}{l}\text { Dates } \\
(1978)\end{array}$ & Latitude & Longitude & $\begin{array}{l}\text { Water } \\
\text { Depth } \\
\text { (m) }\end{array}$ & $\begin{array}{l}\text { Penetration } \\
\text { (m) }\end{array}$ & $\begin{array}{l}\text { Number } \\
\text { of Cores }\end{array}$ & $\begin{array}{l}\text { Meters } \\
\text { Cored }\end{array}$ & $\begin{array}{c}\text { Meters } \\
\text { Recovered }\end{array}$ & $\begin{array}{c}\text { Core } \\
\text { Recovered } \\
(\%)\end{array}$ \\
\hline 467 & 10-18 October & $33^{\circ} 50.97^{\prime} \mathrm{N}$ & $120^{\circ} 45.47^{\prime} \mathrm{W}$ & 2127.8 & 1041.5 & 110 & 1041.5 & 426.30 & 41 \\
\hline 468 & 21-23 October & $32^{\circ} 37.03^{\prime} \mathrm{N}$ & $120^{\circ} 07.07^{\prime} \mathrm{W}$ & 1849.0 & 241.0 & 26 & 241.0 & 83.74 & 34 \\
\hline $468 \mathrm{~A}$ & 23-24 October & $32^{\circ} 37.41^{\prime} \mathrm{N}$ & $120^{\circ} 06.55^{\prime} \mathrm{W}$ & 1737.0 & 35.5 & 4 & 35.5 & 27.69 & 78 \\
\hline 468B & 24-26 October & $32^{\circ} 37.41^{\prime} \mathrm{N}$ & $120^{\circ} 06.55^{\prime} \mathrm{W}$ & 1737.0 & 415.5 & 37 & 351.5 & 104.58 & 30 \\
\hline 469 & 27 Oct.-1 Nov. & $32^{\circ} 37.00^{\prime} \mathrm{N}$ & $120^{\circ} 32.90^{\prime} \mathrm{W}$ & 3790.0 & 453.5 & 51 & 453.5 & 178.46 & 39 \\
\hline 470 & 2-4 November & $28^{\circ} 54.46^{\prime} \mathrm{N}$ & $117^{\circ} 31.11^{\prime} \mathrm{W}$ & 3549.0 & 168.0 & 18 & 168.0 & 90.02 & 54 \\
\hline $470 \mathrm{~A}$ & 4-6 November & $28^{\circ} 54.46^{\prime} \mathrm{N}$ & $117^{\circ} 31.11^{\prime} \mathrm{W}$ & 3549.0 & 215.5 & 13 & 101.5 & 48.21 & 47 \\
\hline 471 & 8-17 November & $23^{\circ} 28.93^{\prime} \mathrm{N}$ & $112^{\circ} 29.78^{\prime} \mathrm{W}$ & 3101.0 & 823.0 & 88 & 823.0 & 356.40 & 43 \\
\hline 472 & 18-19 November & $23^{\circ} 00.35^{\prime} \mathrm{N}$ & $113^{\circ} 59.71^{\prime} \mathrm{W}$ & 3831.0 & 137.5 & 16 & 137.5 & 65.11 & 47 \\
\hline $472 \mathrm{~A}$ & 19-20 November & $23^{\circ} 00.35^{\prime} \mathrm{N}$ & $113^{\circ} 59.71^{\prime} \mathrm{W}$ & 3831.0 & 94.5 & 1 & 0.2 & 0.20 & 100 \\
\hline 473 & 22-26 November & $20^{\circ} 57.92^{\prime} \mathrm{N}$ & $107^{\circ} 03.81^{\prime} \mathrm{W}$ & 3249.0 & 287.5 & 34 & 287.5 & 142.07 & 49 \\
\hline Total & & & & & & 398 & 3640.7 & 1522.78 & 42 \\
\hline
\end{tabular}

a Water depth from sea level.

pachyderma (sensu stricto [s.s.]) is in lower Zone N21 at about $3.0 \mathrm{~m} . y$. ago. The distribution of typical $N$. pachyderma in Hole 467 appears to be in agreement with the Atlantic studies.

The lowest occurrence of Neogloboquadrina dutertrei in conjunction with the last (highest) occurrence of $N$. atlantica are used to approximate the Pliocene/Quaternary boundary between Samples 8-5, $54-56 \mathrm{~cm}$ and 7,CC. Coccoliths and siliceous microfossils, however, indicate the Pliocene/Quaternary boundary is one to two cores lower in the section.

Samples examined that yielded poorly preserved, nondiagnostic taxa or that were barren of planktonic foraminifers include the following: Samples $34, \mathrm{CC}$, $35, \mathrm{CC}, 36-4,40-42 \mathrm{~cm}, 38, \mathrm{CC}, 39, \mathrm{CC}, 41, \mathrm{CC}, 42, \mathrm{CC}$, $43, \mathrm{CC}, 44, \mathrm{CC}, 45, \mathrm{CC}, 47, \mathrm{CC}, 48, \mathrm{CC}, 49, \mathrm{CC}, 50, \mathrm{CC}$, $51, \mathrm{CC}, 52, \mathrm{CC}, 53, \mathrm{CC}, 57, \mathrm{CC}, 59, \mathrm{CC}, 60-1,27-29 \mathrm{~cm}$, 64,CC, 74-1, 77-79 cm, 74,CC, 83,CC, 98,CC, 105-1, $98-100 \mathrm{~cm}$, and $106-1,91-93 \mathrm{~cm}$.

\section{SITE 468}

Site 468 is on the north side of a shallow trough cutting the Patton Escarpment, which is a prominent westward-facing slope delineating the seaward boundary of the California Continental Borderland (Fig. 1). Three holes were drilled at Site 468 . Hole 468 was continuously cored to a sub-bottom depth of 241 meters before caving of volcanogenic sand and breccia forced abandonment of the hole. Following a $1.2 \mathrm{-km}$ upslope displacement, Hole $468 \mathrm{~A}$ was continously cored to 35.5 meters sub-bottom before a broken sand line forced termination of this hole. Finally, Hole 468B was spudded in adjacent to Hole $468 \mathrm{~A}$. Hole $468 \mathrm{~B}$ was washed to 16.5 meters sub-bottom, continously cored to $111.5 \mathrm{me}-$ ters sub-bottom, discontinuously cored from 111.5 to 197.0 meters sub-bottom, and then continuously cored to 405.5 meters sub-bottom. Tables 3 and 4 show occurrences of planktonic foraminifers and other selected constituents of samples from the holes at this site.

\section{Hole 468}

Planktonic foraminifers are abundant and well preserved in Core 1 of Hole 468 and sparse to common and, at best, only moderately well preserved in samples from Cores 2 through 7. Aside from the meager assemblage in Sample 9,CC, the remaining cores from Hole 468 are essentially barren of planktonic foraminifers.

Samples 9,CC through 5-3, 68-70 $\mathrm{cm}$ are assigned to Zones N9 to N10 because of the occurrence of Protentella prolixa in Sample 9,CC and the sporadic occurrence of Globorotalia zealandica up through Core 5. The age assignment deduced from planktonic foraminifers is slightly older than the age assignment derived from coccoliths. Assemblages from Core 4 and Sample $3-3,110-112 \mathrm{~cm}$ are not age diagnostic, but the occurrence of Globigerina druryi in Sample 3,CC is indicative of Zones N11 through N14.

Interpretation of assemblages from Core 2 is equivocal. Middle Miocene planktonic foraminifers, such as Globigerina pseudociperoensis and Globorotalia zealandica, coccoliths, and diatoms occur with the Pliocene marker Globorotalia puncticulata. Are the middle Miocene fossils reworked into Pliocene sediments or do the specimens of Globorotalia puncticulata represent downhole contamination?

Sample 1,CC contains a typical Pliocene (Zone N19) assemblage, and the occurrence of Globigerina calida in Sample 1-1, 3-5 cm reveals the presence of a thin veneer of upper Quaternary (Zone N23) sediments in Hole 468.

Samples examined that yielded sparse, poorly preserved taxa or that were barren of planktonic foraminifers include the following: Samples $11, \mathrm{CC}$, and 12,CC, $13-1,11-13 \mathrm{~cm}, 14, \mathrm{CC}, 15, \mathrm{CC}$, and 17,CC.

\section{Holes 468A and 468B}

Planktonic foraminifers are sparse to abundant and moderately well to poorly preserved in Hole $468 \mathrm{~A}$ and in the first three cores of Hole 468B.

Sparse assemblages in Core 3 of Hole 468B and Sample $4, \mathrm{CC}$ of $468 \mathrm{~A}$ could be either upper Miocene or Pliocene. The transition from Globorotalia puncticulata to $G$. inflata is used to approximate the Zone N19/Zone N21 boundary in Core 1 of Hole 468B and between Cores 3 and 2 of Hole 468A. Assignment of Core 1 of Hole 468A to the Quaternary is suggested by the last occurrences of Neogloboquadrina atlantica and N. humerosa as well as by the first occurrence of $N$. dutertrei in Sample 1,CC. 


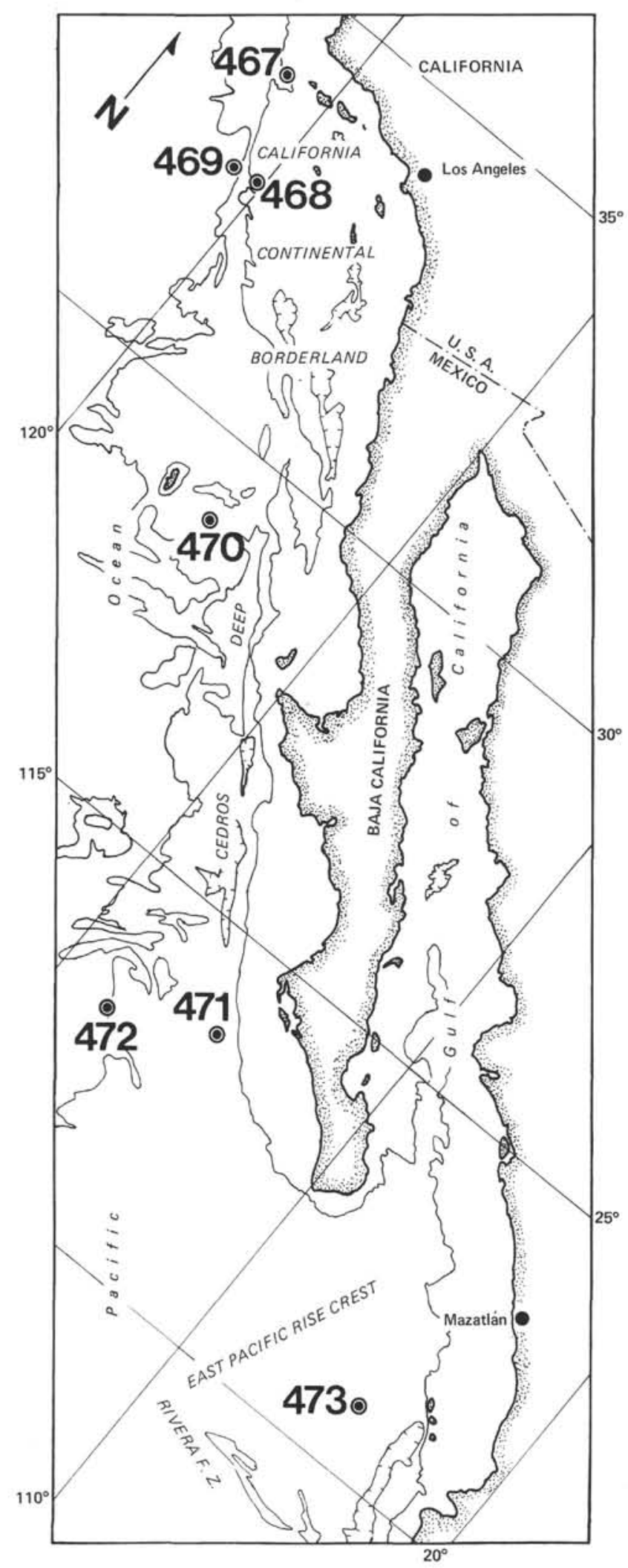

Figure 1. Map showing locations of Leg 63 sites, from Haq and others (1979).
Hole 468B samples examined that were barren of planktonic foraminifers include the following: 4,CC, $6, \mathrm{CC}, 8, \mathrm{CC}, 9, \mathrm{CC}, 10, \mathrm{CC}, 12, \mathrm{CC}, 13, \mathrm{CC}$, and $15, \mathrm{CC}$.

\section{SITE 469}

Site 469 is at the base of the Patton Escarpment to the west of Site 468 (Fig. 1). Planktonic foraminifers are common to abundant in the first 10 cores and sparse or absent in the remaining sediment cores recovered from continuously cored Hole 469. All planktonic assemblages show signs of dissolution. Further, fragments of foraminifers are very abundant in Cores 1 through 10 , and glauconite, foraminifer sands are fairly common in Cores 1 through 5 . These observations suggest that the abundance of planktonic foraminifers in the upper portion of the sedimentary section at this relatively deep $(3,800 \mathrm{~m})$ location is due to downslope displacement from the adjacent Patton Escarpment. The occurrences of planktonic foraminifers and other selected constituents in samples from Hole 469 are shown in Table 5.

The common occurrence of Globorotalia puncticulata in Samples 8,CC and 9,CC along with its sparse occurrence in Sample 11,CC suggest assignment of Cores 11 through 8 to Pliocene Zone N19. The planktonic assemblages in Core 11 are very meager, however, and the assignment for Core 11 must be considered a tentative one.

The transition from Globorotalia puncticulata to $G$. inflata is used to place the Zone N19/N21 boundary within Core 8. The lower limits of Quaternary Zones $\mathrm{N} 22$ and N23 are placed just below the respective first (lowest) occurrences of Neogloboquadrina dutertrei and Globigerina calida in Samples 5,CC and 3-3, 104-106 $\mathrm{cm}$. Note that the last occurrences of Neogloboquadrina atlantica and $N$. humerosa coincide approximately with the first occurrence of $N$. dutertrei.

Samples from Hole 469 that yield sparse, nondiagnostic planktonic foraminifers or that are barren of planktonic foraminifers include the following: Samples $12, \mathrm{CC}, 13, \mathrm{CC}, 14, \mathrm{CC}, 15, \mathrm{CC}, 17, \mathrm{CC}, 19, \mathrm{CC}, 20, \mathrm{CC}$, $22, \mathrm{CC}, 23, \mathrm{CC}, 24, \mathrm{CC}, 25, \mathrm{CC}, 28-1,20-22 \mathrm{~cm}, 34-1$, $10-12 \mathrm{~cm}$, and $37, \mathrm{CC}$.

\section{SITE 470}

Site $\mathbf{4 7 0}$ is located east of Guadalupe Island, Mexico, about $8 \mathrm{~km}$ from the Experimental Mohole Site drilled in 1961. Two holes were drilled at Site 470 . Hole 470 was continuously cored into basement. Recovery in Hole 470 was especially poor between 47.5 and 95.0 meters sub-bottom; therefore this interval, the sediment/basement contact, and basement was recored in Hole 470A. Tables 6 and 7 show the occurrence and relative abundance of planktonic foraminifers and other selected sample constituents in Holes 470 and 470A.

\section{Hole 470}

Planktonic foraminifers in samples from Core 18 represent zonal interval N9 through N11, whereas the 
Table 2. Occurrence and estimated abundance of planktonic foraminifers and other selected components in samples from Hole 467.

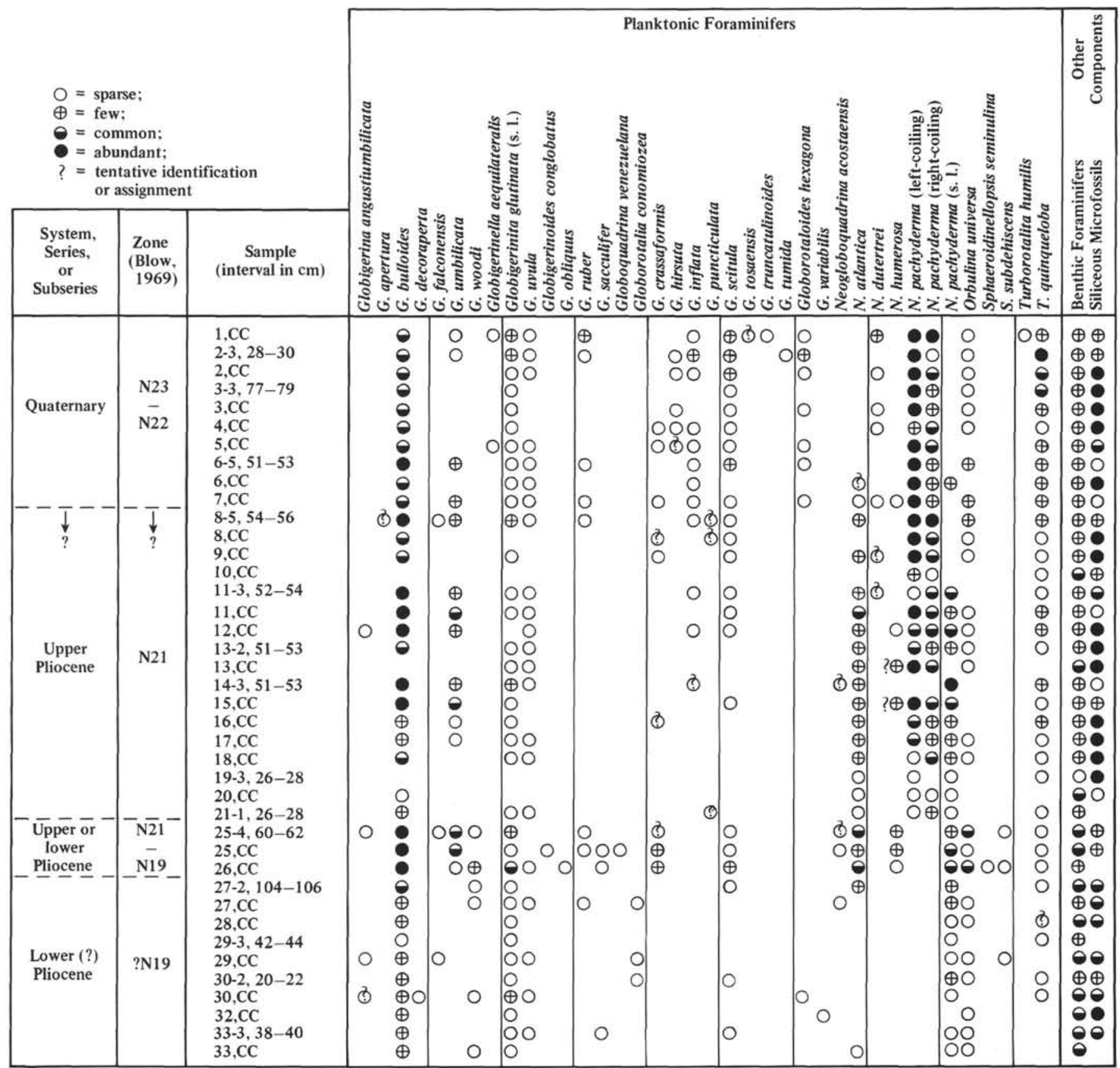

occurrence of Globigerina druryi in Sample 17,CC indicates assignment of Core 17 to Zones N11 or N12. The single occurrence of Sphaeroidinellopsis subdehiscens in Sample 16,CC is used to set the lower boundary of Zone $\mathrm{N} 13$, and the first (lowest) occurrence of Globigerina nepenthes in Sample 15-4, 60-62 cm marks the base of Zone N14. Sparse assemblages from Cores 14 through 12 could represent Zone N14 or N15. Cores 11 through 8 are assigned to upper Miocene Zones N16 to N17 because of the sporadic occurrences of Neogloboquadrina pachyderma (s.1.) in the absence of Pliocene markers. Extremely abundant siliceous microfossils in
Cores 14 through 8 effectively mask planktonic foraminifers.

The base of the Pliocene in Hole 470 is marked by the first occurrences of Globorotalia tumida, G. crassaformis, and G. puncticulata in Sample 7,CC. It is likely that the Miocene/Pliocene boundary coincides with the change upward from diatomaceous silty clay to clay near the top of Core 8. The Zone N19/Zone N21 boundary is indicated by the transition from Globorotalia puncticulata to $G$. inflata in Core 5 , and the last consistent occurrences of Neogloboquadrina atlantica and $N$. humerosa along with the first occurrence of $N$. duter- 
Table 3. Occurrence and estimated abundance of planktonic foraminifers and other selected components in samples from Hole 468.

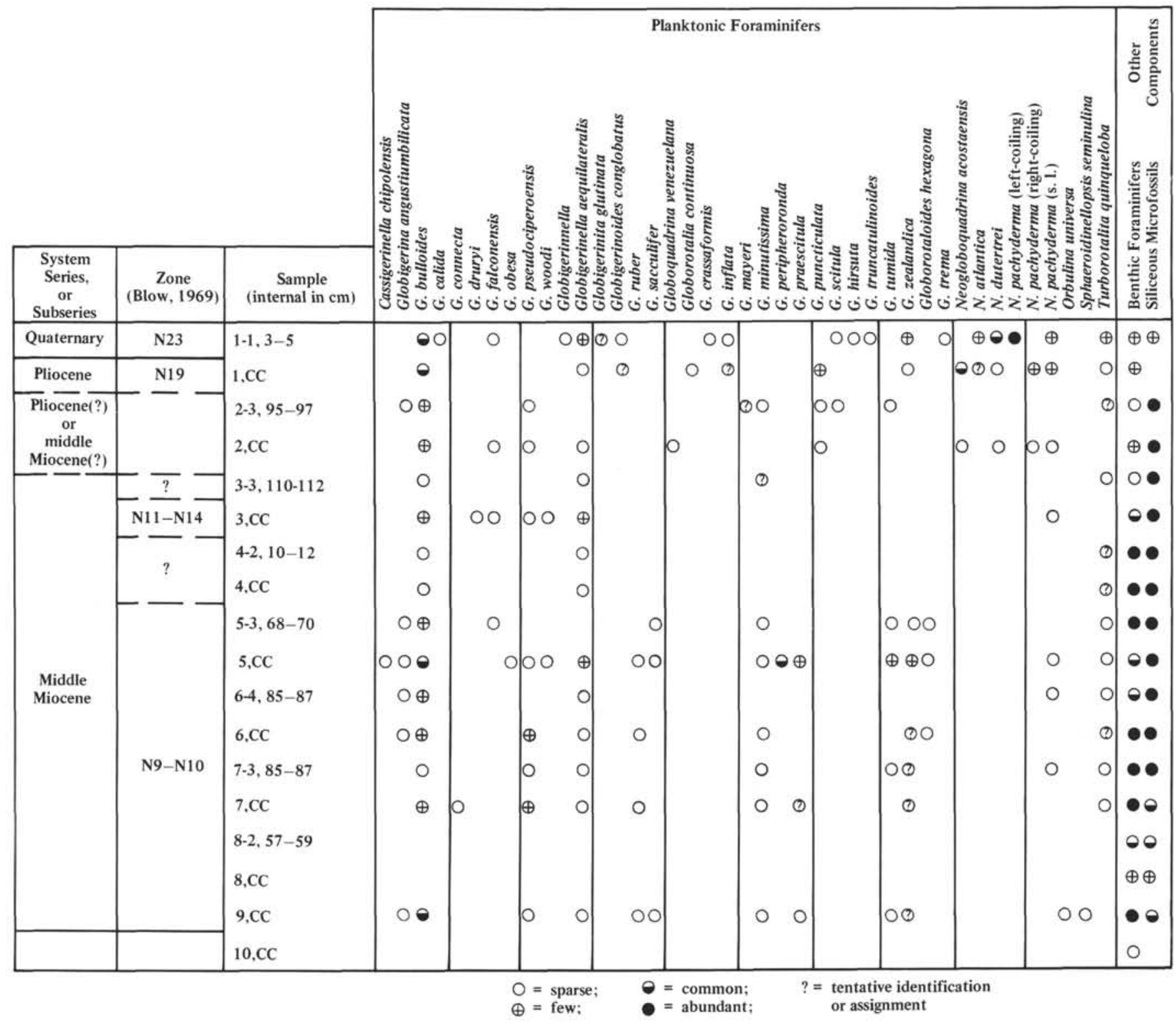

trei are used to approximate the Pliocene/Quaternary boundary.

\section{Hole 470A}

Sparse planktonic foraminifers in Samples 5,CC through 3-1, 60-62 cm could be upper Miocene or lower Pliocene. Coccoliths and siliceous microfossils as well as sub-bottom depth correlation with Hole 470 indicate an upper Miocene assignment for this interval. Cores 2 and 1 are assigned to lower Pliocene Zone N19 because of the occurrences of Globigerinoides conglobatus in Sample 2-2, 30-32 cm and Globigerina nepenthes in Sample $1, \mathrm{CC}$.

Planktonic foraminiferal species and their distributions found in Holes 470 and 470A basically agree with the results of Bandy and Ingle's (1970) study of Ex- perimental Mohole cores. Discrepancies between the two studies are minor and are explained by different taxonomic concepts and the sparse and sporadic occurrence of many species.

\section{SITE 471}

Site 471 is at the distal end of a deep-sea fan west of the foot of the continental slope off Baja California (Fig. 1). Expected age for basement at this continuously cored site was estimated to be about $11 \mathrm{~m}$.y. Planktonic foraminifers are common and well to poorly preserved in Cores 1 through 5 of Hole 471. Fragmentation and etching of foraminifer tests increases downsection. Foraminifers are absent from Cores 6 through 37, but occasional foraminifers were seen on cut surfaces of Cores 38 through 78. Examination of selected samples from 
Table 4. Occurrence and estimated abundance of planktonic foraminifers and other selected components in samples from Holes 468A and 468B.

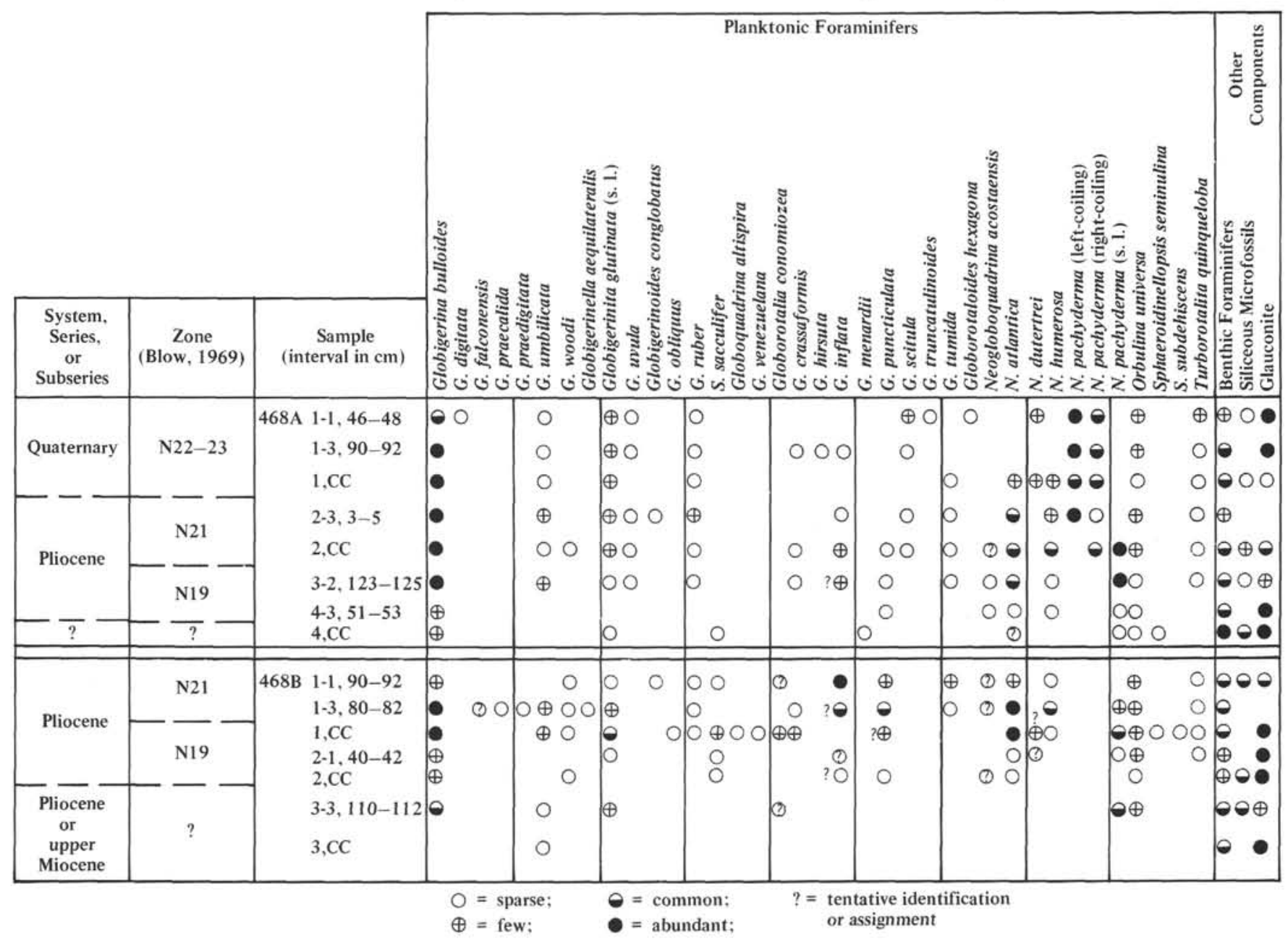

this interval revealed sparse, poorly preserved planktonic foraminifers, and only long-ranging taxa such as Globigerina bulloides and Globigerinoides sacculifer (s.l.) were identified.

Table 8 shows the distribution of planktonic foraminifers and other selected constituents in samples from Cores 1 through 5. Samples 5-2, 80-82 cm through 4-2, 61-63 cm are assigned to Zone N21 because of the consistent occurrence of Globigerinoides obliquus and the sporadic occurrence of Sphaeroidinellopsis spp. and Globorotalia tosaensis. The sparse assemblage from Sample 4-1, 36-38 cm is not diagnostic, but the common occurrence of typical Neogloboquadrina dutertrei combined with the absence of taxa restricted to the Pliocene or older suggests a Quaternary assignment for Sample $3, \mathrm{CC}$. The base of the Quaternary is arbitrarily drawn below Sample 4-1, 36-38 cm on Table 8. Coccoliths from this interval provide clear evidence for a hiatus at the base of Core 3 or the top of Core 4 that corresponds to the latest Pliocene and early Pleistocene. Continuing upsection, the upper portion of Core 1 is assigned to Zone N23 because of the occurrence of Globigerina calida in Samples 1-4, 66-68 cm and 1-1, 66-68 cm.
Note that the occurrences of G. calida in Sample 3-3, $76-78 \mathrm{~cm}$ and Globigerinoides obliquus in Sample 2,CC are interpreted respectively as downhole contamination and reworking.

A significant result of drilling at this site was finding coccoliths indicative of the Sphenolithus heteromorphus Zone at the base of the recovered sedimentary section, which suggests an age of 14 to 15 m.y. for basement.

\section{SITE 472}

Site 472 is located on a small plateau to the west of Site 471 (Fig. 1). Expected age for basement was about 14 m.y., and Hole 472 was continuously cored into basement. Upon completion of drilling at Hole 472, a second hole $(472 \mathrm{~A})$ was washed down to recover the sediment/basalt contact and obtain a heat-flow measurement just above the basalt. But basement was encountered 17.5 meters shallower in Hole 472A than in Hole 472, and therefore no sediment was recovered from Hole 472A.

Planktonic foraminifers are sparse to few in Cores 11 and 12 of the pelagic sequence recovered from Hole 472 (Table 9). All assemblages recovered show effects of dis- 
Table 5. Occurrence and estimated abundance of planktonic foraminifers and other selected components in samples from Hole 469.

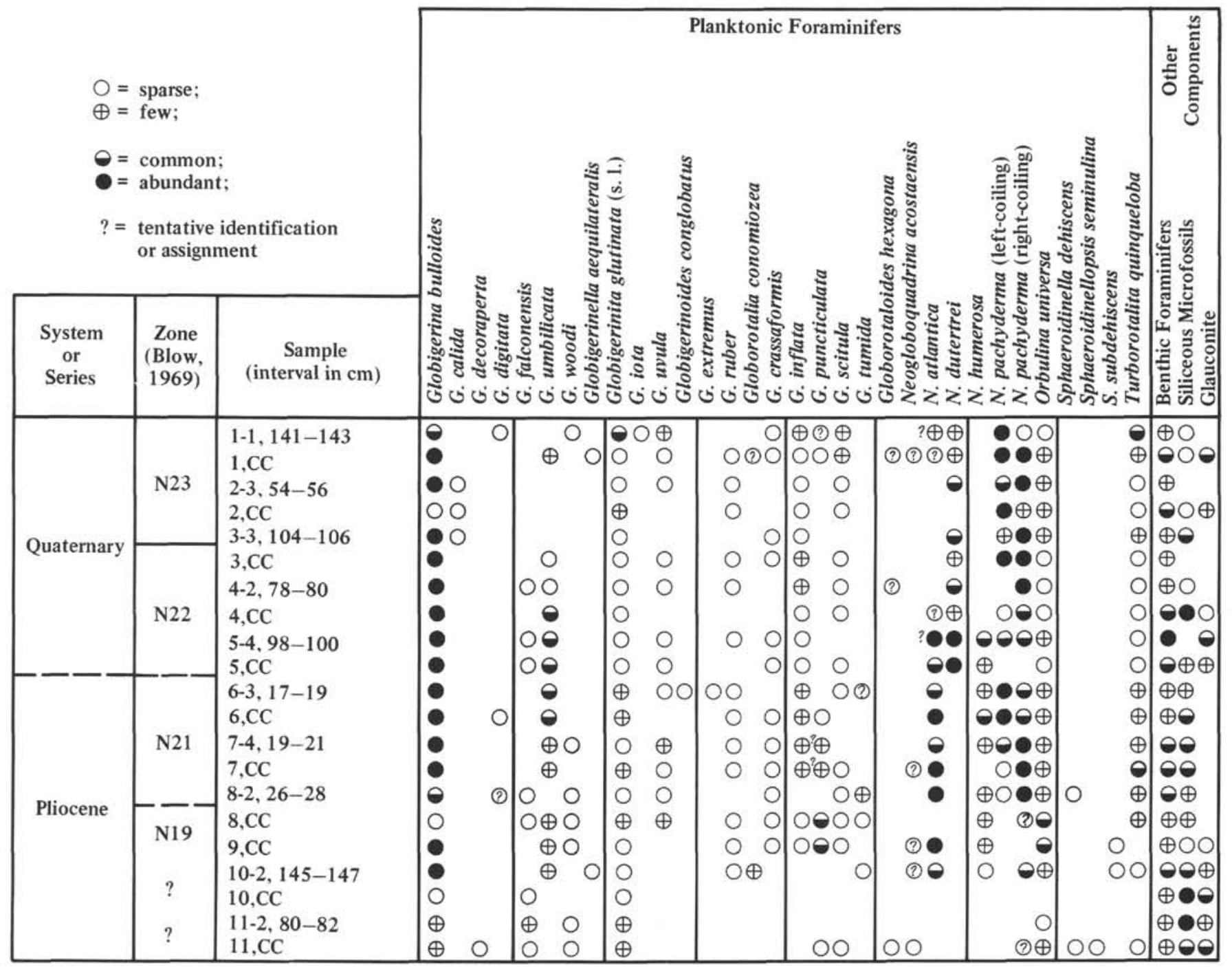

solution, which indicates that the entire sedimentary section was deposited near or below the carbonate compensation depth (CCD).

The occurrence of Globorotalia praefohsi without $G$. fohsi in Sample 11-1, 80-82 cm shows at least part of Core 11 is referable to Zone N11, whereas the occurrence of Orbulina throughout Core 11 and in Sample $12, \mathrm{CC}$ indicates assignment of the rest of Core 11 and Core 12 to Zones N9 to N10. Assignments based on planktonic foraminifers are in good agreement with coccoliths and siliceous microfossil results.

Samples examined that were barren of planktonic foraminifers include: Samples 1, CC, 2, CC, 3, CC, $4, \mathrm{CC}, 5, \mathrm{CC}, 6, \mathrm{CC}, 7, \mathrm{CC}, 8, \mathrm{CC}, 9, \mathrm{CC}$, and 10,CC.

\section{SITE 473}

Site 473 is south of Tres Marias Islands at the mouth of the Gulf of California. Planktonic foraminifers are absent to common and moderately well preserved in samples from Cores 1 through 14 of Hole 473 (Table
10). All planktonic assemblages recovered show signs of dissolution; isolated keels of Globorotalia menardii(?) are present in Samples 1,CC and 2,CC. No planktonic foraminifers were detected below Core 14 .

The occurrence of Sphaeroidinellopsis seminulina and Globoquadrina altispira in Sample 14,CC indicates this level is no younger than about $2.8 \mathrm{~m}$.y. (Zone N21), whereas associated coccoliths suggest a slightly younger assignment (Discoaster surculus Subzone, base about $2.6 \mathrm{~m}$.y. old). The discrepancy, however, is minor. The Pliocene/Quaternary boundary is placed between Samples 10,CC and 9,CC because of the first (oldest) occurrence of Neogloboquadrina dutertrei in Sample 9,CC. This placement is in reasonable agreement with the coccolith data from Hole 473 and suggests that the first (oldest) occurrence of typical $N$. dutertrei can be used in this area to approximate the base of the Quaternary in the absence of Globorotalia truncatulinoides. The occurrence of Globigerina calida in Sample 3,CC indicates assignment of Cores 1 through 3 to Zone N23. Evidence 
Table 6. Occurrence and estimated abundance of planktonic foraminifers and other selected components in samples from Hole 470.

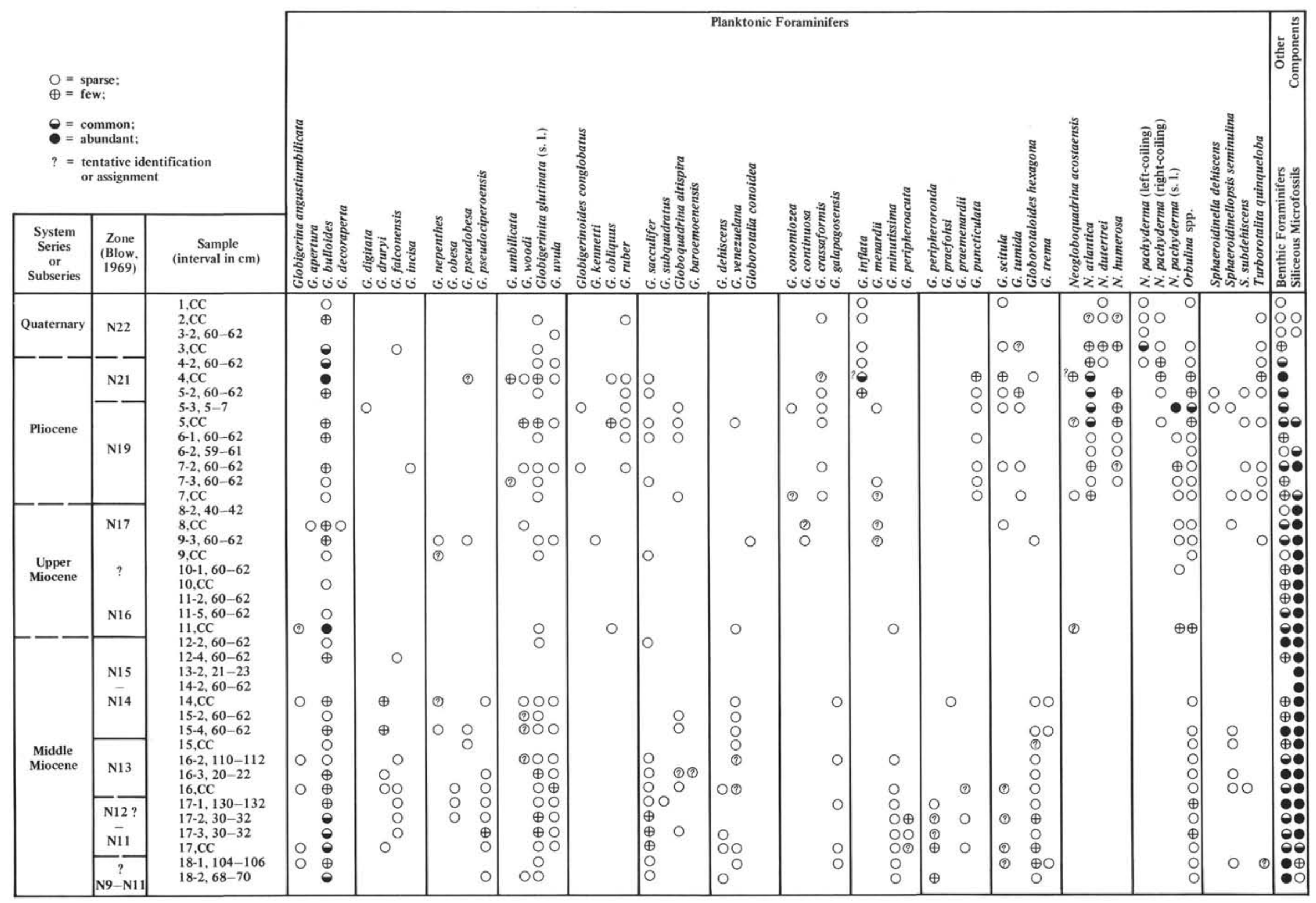


Table 7. Occurrence and estimated abundance of planktonic foraminifers and other selected components in samples from Hole 470A.

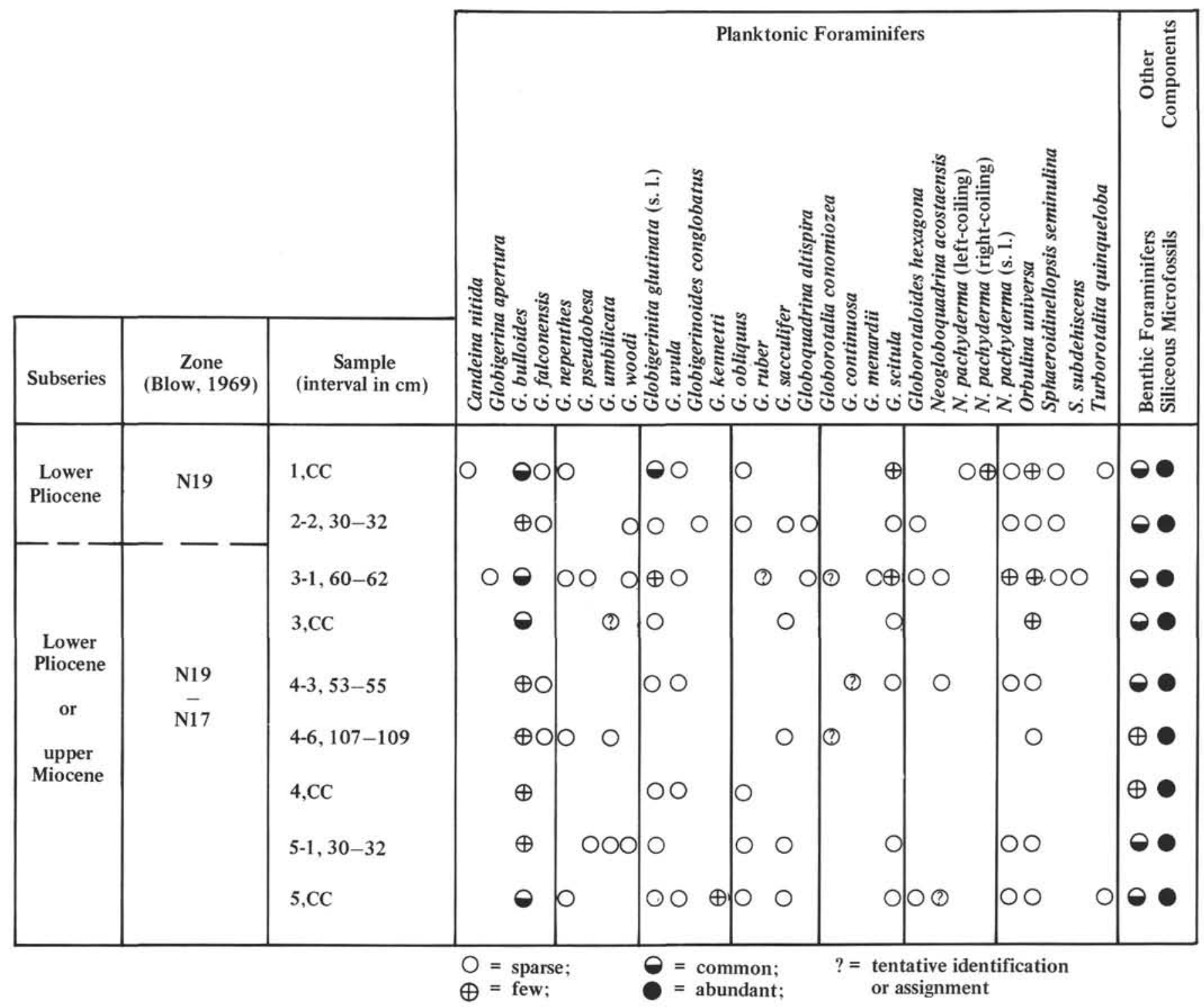

for reworking in the upper part of this section is provided by the presence of Globigerinoides obliquus and Neogloboquadrina atlantica in Sample 4,CC and $N$. atlantica in Sample 2,CC.

Samples examined from Hole 473 that were barren of planktonic foraminifers include: Samples $16, \mathrm{CC}, 17, \mathrm{CC}$, $18, \mathrm{CC}, 19, \mathrm{CC}, 20, \mathrm{CC}, 21, \mathrm{CC}, 22, \mathrm{CC}$, and $28, \mathrm{CC}$.

\section{DISCUSSION}

The record of planktonic foraminifers in Leg 63 sediments is generally disappointing. Dissolution, diagenesis, masking by siliceous and terrigenous material, reworking, and a number of unconformities all contribute to the problem. Two interesting features of the record, however, are the relatively frequent occurrence of Neogloboquadrina atlantica in Pliocene assemblages and the absence of $N$. pachyderma sensu stricto from pre-late Pliocene assemblages. The distribution of these taxa in concert with the stratigraphic distribution of Globorotalia puncticulata, G. crassaformis, G. inflata, Neogloboquadrina humerosa, and $N$. dutertrei define a number of paleontologic datum planes or events that can be used to subdivide sequences of Pliocene through Quaternary subboreal to transitional planktonic foraminiferal faunas of the northeastern Pacific. Further, the same basic sequence of events and resulting associations of planktonic foraminifers are known from the subboreal North Atlantic (Poore, 1979); thus it is possible to correlate low-diversity, high-latitude assemblages within and between the North Pacific and North Atlantic basins.

Figure 2 summarizes the general stratigraphic distribution of key taxa in the North Pacific and North Atlantic. The one interbasin difference demonstrated in Figure 2 concerns the distribution of Neogloboquadrina atlantica. In the North Pacific, $N$. atlantica appears to 
Table 8. Occurrence and estimated abundance of planktonic foraminifers and other selected components in samples from Hole 471.

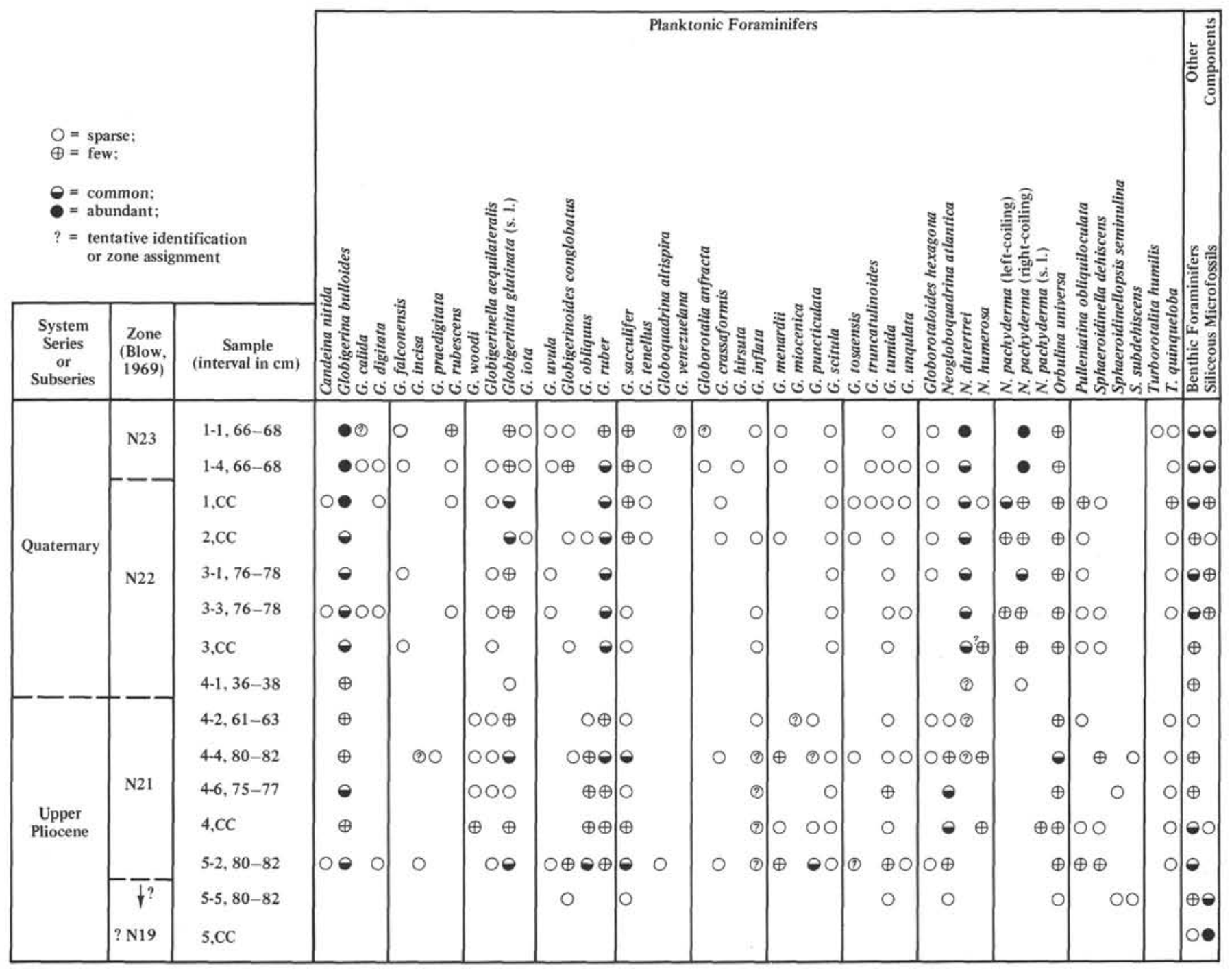

be confined to the Pliocene and is mostly right-coiling. In the North Atlantic, however, right-coiling $N$. atlantica is characteristic of the late Miocene and left-coiling $N$. atlantica is characteristic of the Pliocene (Poore and Berggren, 1975). Regardless of this difference, various combinations of the paleontologic events shown on Figure 2 can be used to recognize, characterize, and correlate similar inter-and intrabasin horizons or intervals.

In contrast to zonal schemes that emphasize events within Globorotalia for extratropical Pliocene through Quaternary correlations (e.g., Kennett, 1973; Poore and Berggren, 1975; Keller, 1978a, b), the sequence of events shown in Figure 2 allows recognition of discrete intervals in subboreal regions where the more temperate Globorotalia may be absent or occur sporadically. This aspect is especially important if one is studying samples from a limited stratigraphic sequence-such as dart core or spot outcrop samples-instead of a long, continuously cored DSDP sequence. For example, although zonally diagnostic Globorotalia are sparse, the occur- rences of Neogloboquadrina atlantica and N. pachyderma s.s. indicate assignment of Cores 21 through 7 of Hole 467 to the late Pliocene. Similarly, zonally diagnostic Globorotalia are essentially absent from Core 11 and lower Core 10 of DSDP Hole 173 off northern California (Keller, 1978b): But samples from this interval contain fairly common Neogloboquadrina atlantica (recorded as $N$. pachyderma form 3 ) and presumably $N$. pachyderma s.s. The sequence of events shown on Figure 2 allows assignment of all of the assemblages from Core 11 and lower Core 10 to the late Pliocene, whereas, aside from the one or two samples that do contain diagnostic Globorotalia, use of the published ranges for species listed for these samples in Keller (1978b) would result in a broad late Miocene to Pliocene assignment.

Another interesting feature of the planktonic foraminiferal record of Leg 63 concerns the paleoclimatic implications of Pliocene assemblages from Holes 467, $468 \mathrm{~A}$ and $\mathrm{B}$, and 470 . Tabulation of the number of warm-water taxa in Pliocene samples from these holes is 
Table 9. Occurrence of planktonic foraminifers and other selected components in samples from Hole 472.

\begin{tabular}{|c|c|c|c|c|c|c|c|c|}
\hline & & & \multirow{2}{*}{ 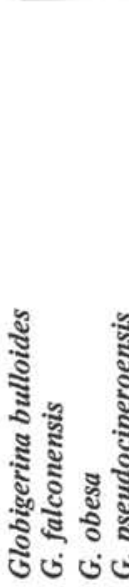 } & \multicolumn{4}{|c|}{ Planktonic Foraminifers } & \multirow{2}{*}{ 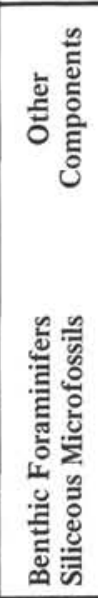 } \\
\hline $\begin{array}{l}\text { Sub- } \\
\text { series }\end{array}$ & $\begin{array}{c}\text { Zone } \\
\text { (Blow, 1969) }\end{array}$ & $\begin{array}{c}\text { Sample } \\
\text { (interval in } \mathrm{cm} \text { ) }\end{array}$ & & \multicolumn{4}{|c|}{ 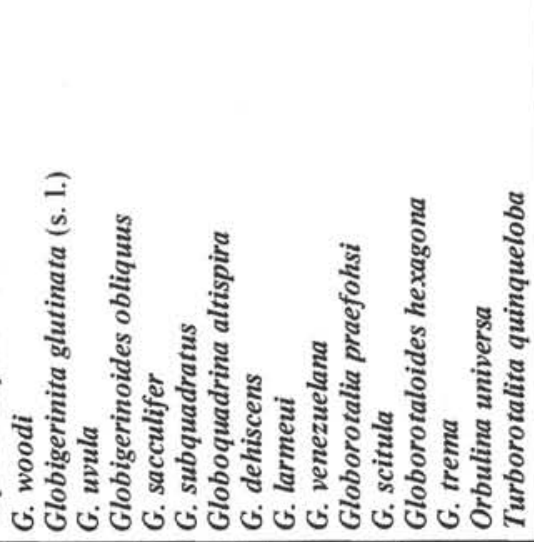 } & \\
\hline \multirow{8}{*}{$\begin{array}{l}\text { Middle } \\
\text { Miocene }\end{array}$} & \multirow{8}{*}{ N9-N10 } & $11-1,80-82$ & $\times \quad \times x$ & $x \times x$ & $\mid x \quad x$ & $? \times \times ?$ & $x \quad x$ & $x \times$ \\
\hline & & $11-2,60-62$ & $x$ & $\times x$ & $x \quad x$ & $x$ & $x$ & $x \times$ \\
\hline & & $11-3,80-82$ & & $x$ & $|x x \quad x|$ & $x$ & $x \times$ & \\
\hline & & $11-4,111-113$ & $x \times$ & $x \times$ & $x \times x$ & & $\times \times$ ? & $x \times$ \\
\hline & & $11, \mathrm{CC}$ & $x$ & & $x$ & $x$ & & $x \times$ \\
\hline & & $12-1,11-13$ & & & & $x$ & & $\times x$ \\
\hline & & $12-2,15-17$ & & & & & & $x \times$ \\
\hline & & $12, \mathrm{CC}$ & $x \times$ & $x$ & $x$ & $x$ & $x$ & $x \times$ \\
\hline
\end{tabular}

shown in Figure 3. The tabulation indicates that two northward excursions of warm-water taxa took place during the Pliocene. The first or oldest event is represented by the assemblages in Core 7 of Hole 470 . Sediment accumulation rate calculations for Hole 470 (see Site Report) suggest that this event took place at about 4.0 m.y. ago. Note there is no clear indication of this early Pliocene warm event in the California Continental Borderland sites.

A second warm event is represented by assemblages in Core 5 of Hole 470, Core 2 of Hole 468A, Core 1 of Hole 468B, and Cores 26 and 25 of Hole 467. This younger Pliocene event is associated with the coccolith Discoaster tamalis Subzone and is therefore dated at about 2.7 to $2.8 \mathrm{~m} . \mathrm{y}$. ago. Although the data from Leg 63 are sketchy, poleward migration of warm-water assemblages at about 4.0 and $2.8 \mathrm{~m} . y$. ago is compatible with that indicated by faunal studies at DSDP Sites 310 and 173 (Keller, 1978a, b) and California onshore sections (Ingle, 1973b).

\section{TAXONOMIC NOTES}

The original references to all species identified and plotted on Tables 2 through 10 are listed below. Discussion and comments are provided for selected taxa.

\section{Candeina nitida d'Orbigny}

Candeina nitida d'Orbigny, 1839a, p. 108, pl. 2, figs. 27, 28.
Cassigerinella chipolensis (Cushman and Ponton)

Cassidulina chipolensis Cushman and Ponton, 1932, pl. 15, fig. 2.

Globigerina angustiumbilicata Bolli

Globigerina ciperoensis angustiumbilicata Bolli, 1957, p. 109, pl. 22, figs. 12,13 .

Globigerina apertura Cushman

Globigerina apertura Cushman, 1918, p. 57, pl. 12, fig. 8.

Globigerina bulloides d'Orbigny

Globigerina bulloides d'Orbigny, 1826, p. 277.

Globigerina calida Parker

Globigerina calida Parker, 1962, p. 221, pl. 1, figs. 9-13, 15.

Globigerina connecta Jenkins

Globigerina woodi connecta Jenkins, 1964, p. 72, text-fig. 1.

Globigerina decoraperta Takayanagi and Saito

Globigerina druryi decoraperta Takayanagi and Saito, 1962, p. 85, pl. 28, fig. 10 .

\section{Globigerina digitata Brady}

Globigerina digitata Brady, 1879, p. 286.

\section{Globigerina druryi Akers}

(Plate 5, Fig. 9)

Globigerina druryi Akers, 1955, p. 654, pl. 65, fig. 1. 


\section{R. Z. POORE}

Table 10. Occurrence and estimated abundance of planktonic foraminifers and other selected components in samples from Hole 473.

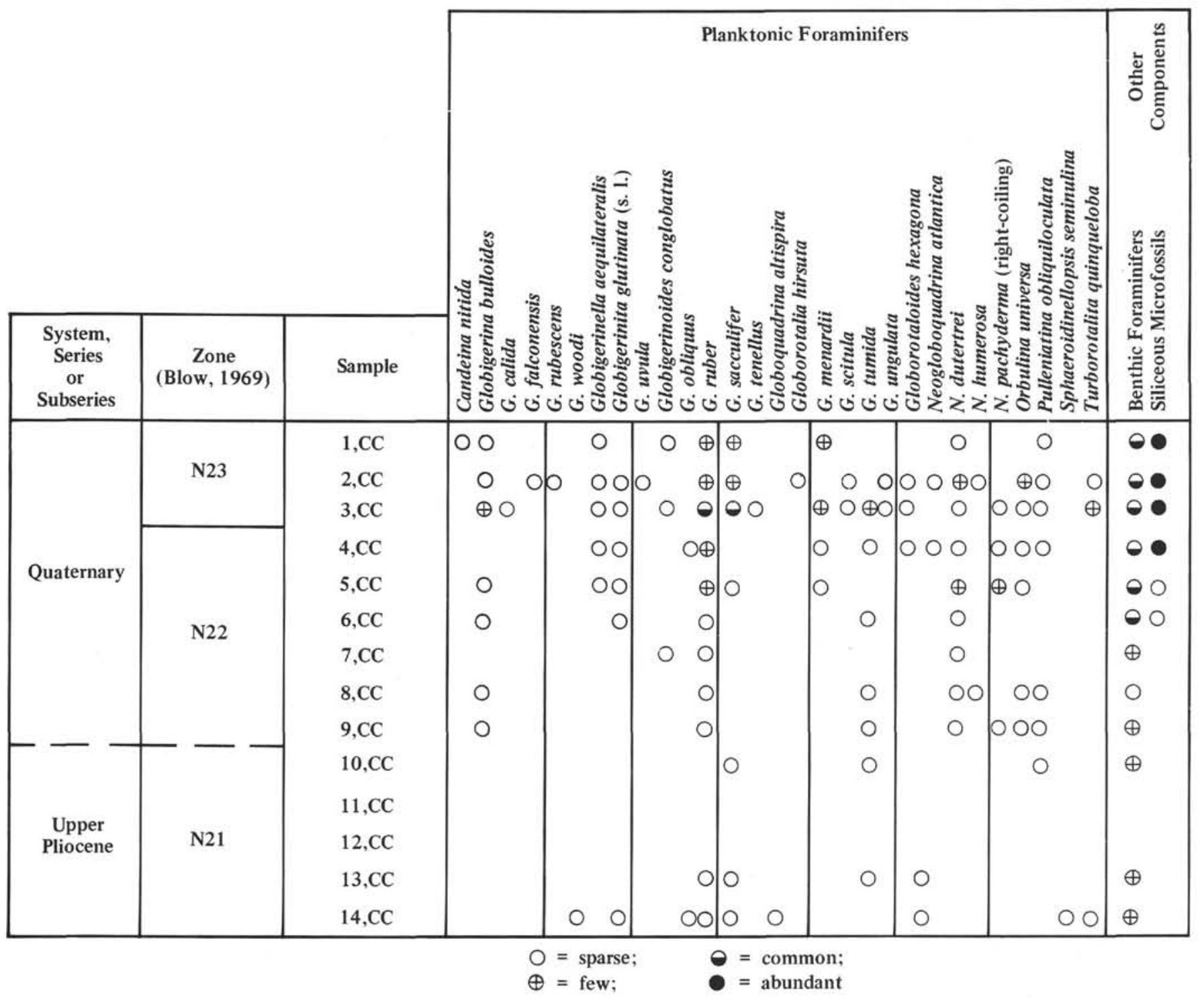

Globigerina falconensis Blow

Globigerina falconensis Blow, 1959, p. 177, pl. 9, figs. 40, 41.

\section{Globigerina incisa (Brönimann and Resig)} (Plate 4, Fig, 9)

Globorotalia incisa Brönnimann and Resig, 1971, p. 1278, pl. 45, figs. 5,7 ; pl. 46, figs. $1-8$.

Scanning electron microscope studies show this species possesses spines and is therefore referable to Globigerina (Poag and Valentine, 1976).

\section{Globigerina nepenthes Todd}

(Plate 5, Fig. 8)

Globigerina nepenthes Todd, 1957, p. 301, pl. 78, fig. 7.

\section{Globigerina obesa (Bolli)}

Globorotalia obesa Bolli, 1957, p. 119, pl. 29, figs. 2, 3.

\section{Globigerina praecalida Blow}

Globigerina calida praecalida Blow, 1969, p. 380, pl. 13, figs. 6, 7; pl. 14 , fig. 3 .
Globigerina praedigitata Parker

Globigerina praedigitata Parker, 1967, p. 151, pl. 19, figs. 5-8.

\section{Globigerina pseudobesa (Salvatorini)}

Turborotalia pseudobesa Salvatorini, 1966, p. 10, pl. 2, figs. 6-15.

\section{Globigerina pseudociperoensis Blow}

(Plate 1, Figs. 9, 10)

Globigerina praebulloides pseudociperoensis Blow, 1969, p. 381, pl. 17 , figs. 8,9 .

The taxon I refer to Globigerina pseudociperoensis in this report has been recorded as Globigerina concinna Reuss in other studies of eastern North Pacific lower and middle Miocene sediments (e.g., Bandy and Ingle, 1970; Ingle, 1973a). In my opinion, however, considerable confusion surrounds the name "Globigerina concinna." The original material is lost but may have been described from Tortonian (upper Miocene) strata (Bolli, 1954). In lieu of an adequate original illustration and original material, the specimen illustrated by Marks (1951) is usually referenced to establish the concept of $G$. concinna, but adequate locality and age information are not given for the illustrated specimen. Therefore I prefer to use the better defined and 


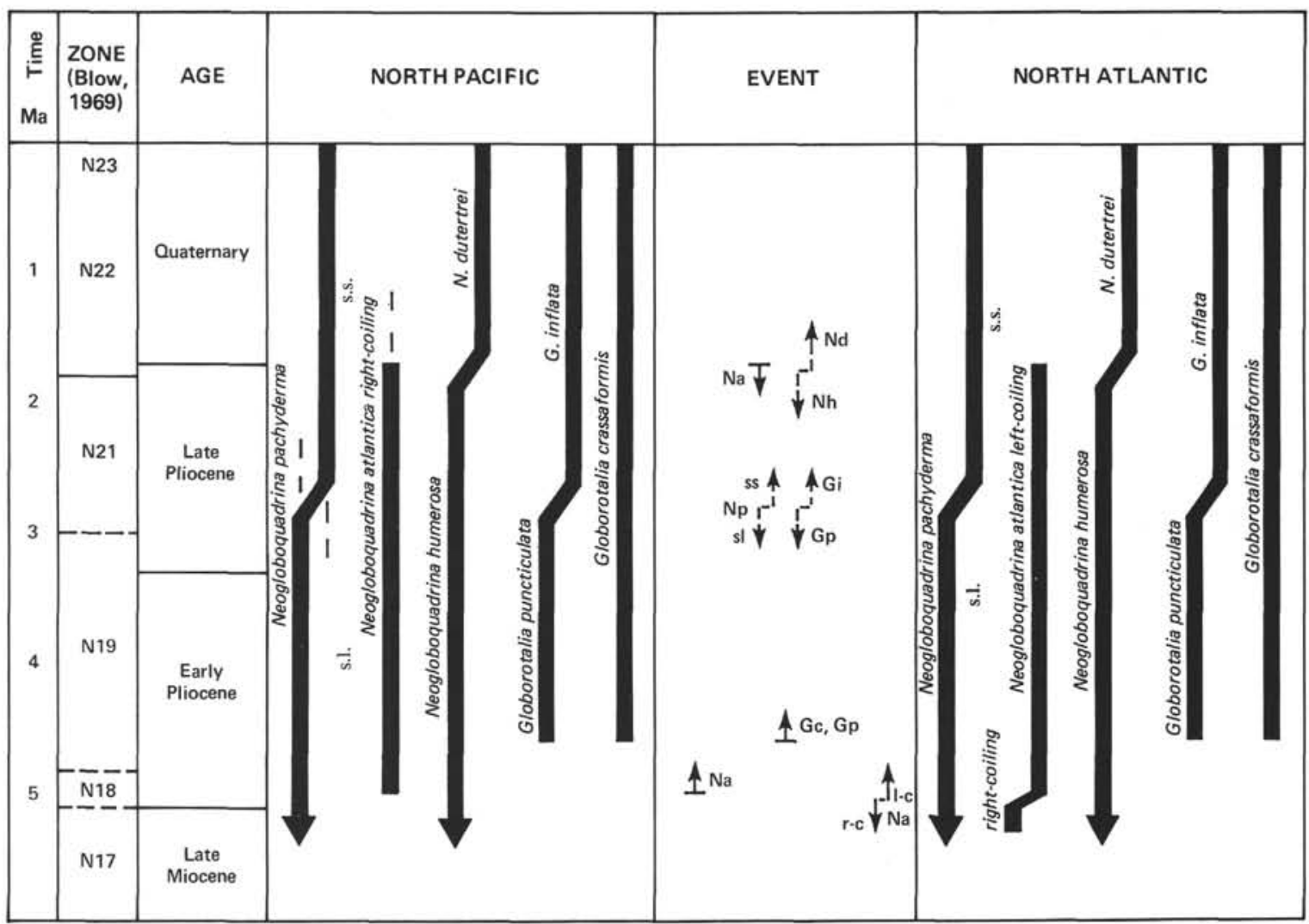

Figure 2. Comparison of stratigraphic distribution of selected Neogloboquadrina and Globorotalia between the North Pacific and North Atlantic. (Key: $\Lambda=$ first occurrence; $\downarrow=$ last occurrence; $\boldsymbol{F}^{\boldsymbol{T}}=$ coiling change; $r^{-}=$evolutionary transition; $\mathrm{Na}=$ Neogloboquadrina atlantica $; \mathrm{Np}=N$. pachyderma $; \mathrm{Nh}=N$. humerosa $; \mathrm{Nd}=N$. dutertrei; $\mathrm{Gp}=$ Globorotalia puncticulata; $\mathrm{Gc}=G$. crassaformis; $\mathrm{Gi}=G$. inflata; $\mathrm{r}-\mathrm{c}=$ right-coiling; 1 -c $=$ left-coiling; s.s. = sensu stricto; s.l. = sensu lato.)
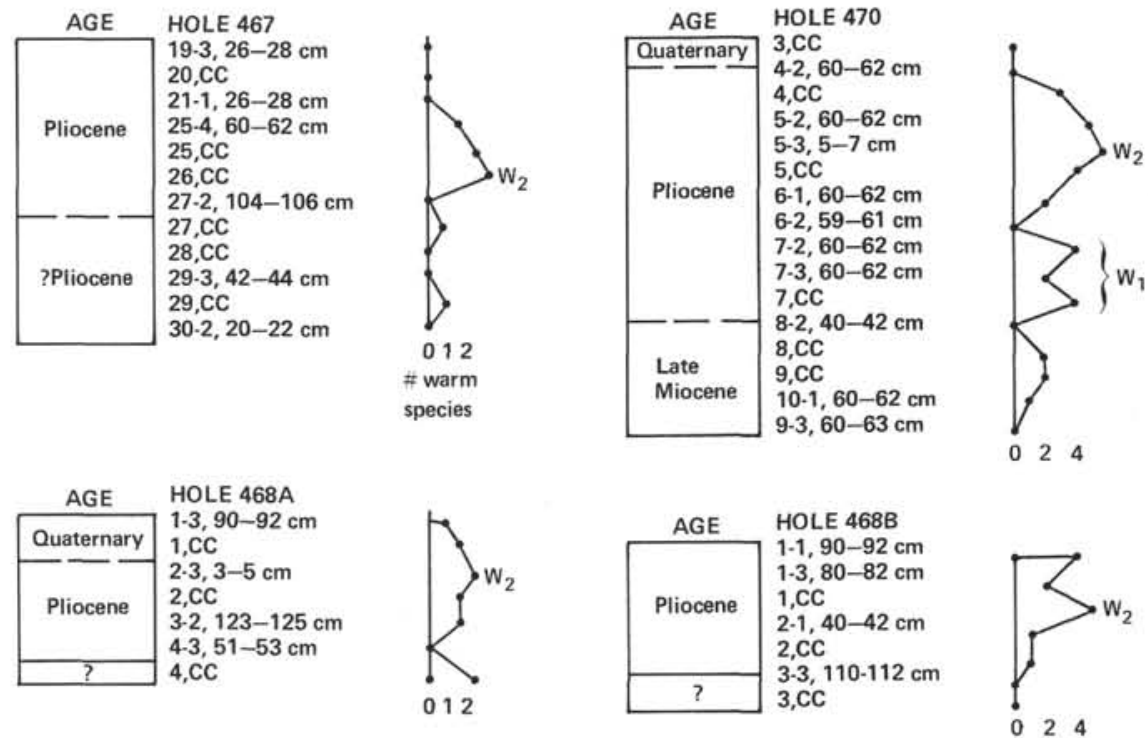

Figure 3. Tabulation of "warm-water" planktonic foraminifer species in late Cenozoic samples of Holes 467, 468A, 468B, and 470. (Taxa counted as warm indicators are: Globigerinoides spp., Globorotalia tumida, G. menardii, Sphaeroidinellopsis spp., and Sphaeroidinella dehiscens. Plots suggest northern incursions of warm-water taxa took place during the Pliocene about $4.0 \mathrm{~m} . \mathrm{y}$. ago $\left[\mathrm{W}_{1}\right]$ and $2.8 \mathrm{~m} . \mathrm{y}$. ago $\left[\mathrm{W}_{2}\right]$. See text for discussion.) 
well-illustrated name Globigerina pseudociperoensis for the lower to middle Miocene five-chambered Globigerina found in Leg 63 samples.

\section{Globigerina rubescens Hofker}

Globigerina rubescens Hofker, 1956, p. 234, pl. 35, figs. 18-21.

\section{Globigerina umbilicata Orr and Zaitzeff}

(Plate 4, Figs. 7, 8)

Globigerina umbilicata Orr and Zaitzeff, 1971, p. 18, pl. 1, figs. 1-3.

\section{Globigerina woodi Jenkins}

Globigerina woodi Jenkins, 1960, p. 352, pl. 2, fig. 2.

Globigerina aequilateralis (Brady)

Globigerina aequilateralis Brady, 1879, p. 285.

Globigerinita glutinata (Egger) s.l.

Globigerina glutinata Egger, 1893, p. 371, pl. 13, figs. 19-21.

Globigerinita ambitacrena (Loeblich and Tappan), G. incrusta

Akers, and $G$. naparimaensis Brönnimann are included in $G$. glutinata (s.1.).

\section{Globigerinita iota Parker}

Globigerinita iota Parker, 1962, p. 250, pl. 10, figs. 26-30.

\section{Globigerinita uvula (Ehrenberg)}

Pylodexia uvula Ehrenberg, 1861, p. 308.

Globigerinoides conglobatus (Brady)

Globigerina conglobata Brady, 1879, p. 286.

Globigerinoides extremus Bolli and Bermudez

Globigerinoides obliquus extremus Bolli and Bermudez, 1965, p. 139, pl. 1, figs. 10-12.

\section{Globigerinoides kennetti Keller and Poore}

(Plate 3, Fig. 7, 8)

Globigerinoides kennetti Keller and Poore, 1980, p. 189.

Globigerinoides obliquus Bolli

Globigerinoides obliqua Bolli, 1957, p. 113, pl. 25, figs. 9, 10; text-fig. 21 , no. 5 .

Globigerinoides ruber (d'Orbigny)

Globigerina rubra d'Orbigny, 1839a, p. 82, pl. 4, figs. 12-14.

Globigerinoides sacculifer (Brady) s.I.

Globigerina sacculifera Brady, 1877, p. 535.

Globigerinoides trilobus (Reuss) is included in G. sacculifer (s.I.).

Globigerinoides subquadratus Brönnimann

Globigerinoides subquadrata Brönnimann, 1954, in Todd et al., 1954, p. 680 , pl. 1 , figs. 5,8 .

\section{Globigerinoides tenellus Parker}

Globigerinoides tenellus Parker, 1958, p. 280, pl. 6, figs. 7-11.

Globoquadrina altispira (Cushman and Jarvis)

Globigerina altispira Cushman and Jarvis, 1936, p. 5, pl. 1, figs, 13, 14.

Globoquadrina baroemoenenis (LeRoy)

(Plate 3, Fig. 9)

Globigerina baroemoenenis LeRoy, 1939, p. 263, pl. 6, figs. 1 and 2.
Globoquadrina dehiscens (Chapman, Parr, and Collins)

Globorotalia dehiscens Chapman, Parr, and Collins, 1934, p. 569, pl. 11, fig. 6 .

\section{Globoquadrina larmeui Akers}

Globoquadrina larmeui Akers, 1955, p. 661, pl. 65, fig. 4.

$$
\text { Globoquadrina venezuelana (Hedberg) }
$$

Globigerina venezuelana Hedberg, 1937, p. 681, pl. 92, fig. 7.

Globorotalia anfracta Parker

Globorotalia anfracta Parker, 1967, p. 175, pl. 28, figs. 3-8.

Globorotalia conoidea Walters

Globorotalia miozea conoidea Walters, 1965, p. 124, fig. 8, I-M.

Globorotalia conomiozea Kennett

(Plate 3, Figs. 5, 6)

Globorotalia conomiozea Kennett, 1966, p. 235, pl. 1, figs. 8-18; pl. 2, figs. 6-13; text-fig. 10.

Globorotalia continuosa Blow

Globorotalia opima continuosa Blow, 1959, p. 218, pl. 19, fig. 125.

Globorotalia crassaformis (Galloway and Wissler)

Globigerina crassaformis Galloway and Wissler, 1927, p. 41, pl. 7, fig. 12.

\section{Globorotalia galapagosensis Quilty}

(Plate 2, Figs. 8-10)

Globorotalia galapagosensis Quilty, 1978, p. 332.

Globorotalia akersi Quilty, 1976, p. 647, pl. 14, figs. 9-13.

This minute but distinctive species occurs sporadically in the middle Miocene section of Hole 470. At equatorial Pacific DSDP Site 319 Quilty (1976) found Globorotalia galapagosensis (as G. akersi) to be confined to Zone N12. The results from Hole 470 , however, show that Globorotalia galapagosensis can range up to Zone N14. Globorotalia bauerensis, a taxon that is very similar to $G$. galapagosensis, was not detected in Hole 470.

\section{Globorotalia hirsuta (d'Orbigny)}

Rotalina hirsuta d'Orbigny, 1839b, in Barker-Webb and Berthelot, 1839 , p. 131 , pl. 1, figs. $37-39$.

\section{Globorotalia inflata (d'Orbigny)}

(Plate 3, Figs. 1, 2)

Globigerina inflata d'Orbigny, $1839 \mathrm{~b}$, in Barker-Webb and Berthelot, 1839 , p. 134 , pl. 2 , figs. $7-9$.

\section{Globorotalia mayeri Cushman and Ellisor}

Globorotalia mayeri Cushman and Ellisor, 1939, p. 11, pl. 2, fig. 4.

Globorotalia menardii (Parker, Jones, and Brady)

Rotalia menardii Parker, Jones, and Brady, 1865, p. 20, pl. 3, fig. 81.

Globorotalia minutissima Bolli

(Plate 2, Figs. 1-3)

Globorotalia minutissima Bolli, 1957, p. 119, pl. 29, fig. 1.

Globorotalia miocenica Palmer

Globorotalia miocenica Palmer, 1945, p. 70, pl. 1, fig. 10.

\section{Globorotalia peripheroacuta Blow and Banner} (Plate 2, Figs. 4-7)

Globorotalia peripheroacuta Blow and Banner, 1966, p. 294, pl. 1, fig. 2 ; pl. 2, figs. 4,5 , and 13 . 
Globorotalia peripheroronda Blow and Banner

Globorotalia peripheroronda Blow and Banner, 1966, p. 294, pl. 1, fig. 1 ; pl. 2, figs. 1-3.

Globorotalia praefohsi Blow and Banner

Globorotalia praefohsi Blow and Banner, 1966, p. 295, pl. 1, figs. 3 and 4 ; pl. 2, figs. 6, 7, 10, 11 .

\section{Globorotalia praemenardii Cushman and Stainforth}

Globorotalia praemenardii Cushman and Stainforth,1945, p. 70, pl. 13 , fig. 14.

Globorotalia praescitula Blow

Globorotalia scitula praescitula Blow, 1959, p. 221, pl. 19, fig. 128.

Globorotalia puncticulata (Deshayes)

(Plate 3, Figs. 3, 4)

Globigerina puncticulata Deshayes, 1832, p. 170.

Globorotalia scitula (Brady)

Pulvinulina scitula Brady, 1882, p. 716.

\section{Globorotalia tosaensis Takayanagi and Saito}

Globorotalia tosaensis Takayanagi and Saito, 1962, p. 81, pl. 28, figs. $11,12$.

\section{Globorotalia truncatulinoides (d'Orbigny)}

Rotalina truncatulinoides d'Orbigny, 1839b, in Barker-Webb and Berthelot, 1839, p. 132, pl. 2, figs. 25-27.

Globorotalia tumida (Brady)

Pulvinulina menardii var, tumida Brady, 1877 , p. 535.

\section{Globorotalia ungulata Bermudez}

Globorotalia ungulata Bermudez, 1961, p. 1304, pl. 15, fig. 6.

Globorotalia zealandica Hornibrook

Globorotalia zealandica Hornibrook, 1958, p. 667, figs. 18, 19, 30.

Globorotaloides hexagona (Natland)

(Plate 1, Figs. 1-3)

Globigerina hexagona Natland, 1938, p. 149, pl. 7, fig. 1.

More spherical to globular chambers and straight spiral sutures serve to distinguish Globorotaloides hexagona from its presumed ancestor Globorotaloides variabilis.

\section{Globorotaloides trema Lipps}

(Plate 1, Figs. 4-8)

Globorotaloides trema Lipps, 1964, p. 128, pl. IV, fig. 3.

This minute species is distinguished by its small size and nonspinose, reticulate test surface texture. Globorotaloides trema appears to be restricted to the North Pacific Basin, but its small size may cause it to be overlooked during routine analyses.

Globorotaloides variabilis Bolli

Globorotaloides variabilis Bolli, 1957, p. 117, pl. 27, figs. 15-20.

Neogloboquadrina acostaensis (Blow)

Globorotalia acostaensis Blow, 1959, p. 208, pl. 17, figs. 106, 107.

\section{Neogloboquadrina atlantica (Berggren)}

(Plate 4, Figs. 1-3)

Globigerina atlantica Berggren, 1972, p. 972, pl. 1, figs. 1-7; pl. 2, figs, $5-8$.

Neogloboquadrina atlantica is a characteristic component of Pliocene planktonic foraminiferal assemblages at Sites 467 through 471 . In these northeastern Pacific sediments, $N$. atlantica is typically robust, large, right-coiling, possesses four to four-and-one-half globular chambers in the ultimate whorl, has a deep and open umbilicus, and an extra-umbilical to umbilical aperture that is often bordered by a lip. In contrast, North Atlantic representatives of $N$. atlantica are usually left-coiling in the Pliocene, right-coiling in the upper Miocene, and the change from right- to left-coiling is used to approximate the Miocene/Pliocene boundary (Poore and Berggren, 1975; Poore, 1979). In other respects, North Atlantic and North Pacific populations of $N$. atlantica are very similar.

Neogloboquadrina pachyderma (s.s. and s.I.) and N. acostaensis are smaller and more compact than $N$. atlantica. In addition, $N$. acostaensis has less globular chambers and a flatter spiral side than $N$. atlantica. The larger number $(>5)$ of chambers in the outer whorl of Neogloboquadrina humerosa serve to distinguish it from $N$. atlantica.

Neogloboquadrina pachyderma form 3 of Keller (1978c) $(=$ Globoquadrina asanoi) and some specimens of $N$. pachyderma form 2 of Keller (1978c), as well as Globoquadrina asanoi Maiya, Saito, and Sato, G. kagaensis Maiyo, Saito, and Sato, and perhaps G. himiensis Maiyo, Saito, and Sato are referable to Neogloboquadrina atlantica. Studies of North Pacific DSDP Holes 173 and 310 by Keller (1978a, b, c) corroborate the essentially restricted Pliocene distribution for $\mathrm{NeO}$ globoquadrina atlantica seen in Leg 63 materials.

\section{Neogloboquadrina dutertrei (d'Orbigny)}

(Plate 4, Fig. 6)

Globigerina dutertrei d'Orbigny, 1839a, p. 84, pl. 4, figs. 19-21.

\section{Neogloboquadrina humerosa (Takayanagi and Saito)} (Plate 4, Figs. 4, 5 )

Globorotalia humerosa Takayanagi and Saito, 1962, p. 78, pl. 28, figs. $1,2$.

\section{Neogloboquadrina pachyderma (Ehrenberg)}

(Plate 5, Figs. 1-7)

Aristerospira pachyderma Ehrenberg, 1861, p. 303.

Typical or modern-looking Neogloboquadrina pachyderma was only detected in upper Pliocene and Quaternary sediments of Leg 63. A closely related form, or $N$. pachyderma s.l., is present, however, in upper Miocene through upper Pliocene sediments. The equatorial outline of the older form is usually circular to subquadrate, whereas the equatorial outline of $N$. pachyderma s.s. is often oval. In addition, the older forms do not usually develop the glassy- to sugary-textured secondary encrustation common in $N$. pachyderma s.s. Differentiation of the two forms is difficult in some samples, and the timing of establishment of populations of modern Neogloboquadrina pachyderma needs further documentation. Nonetheless, recognition of these two forms provides a means for separating upper Miocene to lower Pliocene from upper Pliocene to Quaternary low-diversity, subboreal, planktonic foraminiferal assemblages.

\section{Orbulina universa d'Orbigny}

Orbulina universa d'Orbigny, 1839a, in Sagra, Ramon de la, p. 3, pl. 1 , fig. 1.

Orbulina suturalis Bronnimann is included with $O$. universa in this report.

\section{Protentella prolixa Lipps}

Protentella prolixa Lipps, 1964, p. 124, pl. II, figs. 8, 9.

Only one broken specimen of this distinctive species was found in Core 9 of Hole 468 .

\section{Pulleniatina obliquiloculata (Parker and Jones)}

Pullenia sphaeroides var. obliquiloculata Parker and Jones, 1865, p. 365 , pl. 19, fig. 4 .

\section{Sphaeroidinella dehiscens (Parker and Jones)}

Sphaeroidina bulloides var. dehiscens Parker and Jones, 1865, p. 369, pl. 19 , fig. 5 .

Sphaeroidinellopsis seminulina (Schwager)

Globigerina seminulina Schwager, 1866, p. 267, pl. 7, fig. 112. 
Sphaeroidinellopsis subdehiscens (Blow)

Sphaeroidinella dehiscens subdehiscens Blow, 1959, p. 195, pl. 12, figs. 71,72 .

Turborotalita humilis (Brady)

Truncatulina humilis Brady, 1884, p. 665, pl. 94, fig. 7.

Turborotalita quinqueloba (Natland)

Globigerina quinqueloba Natland, 1938, p. 149, pl. 6, fig. 7.

\section{ACKNOWLEDGMENTS}

I thank J. A. Barron and G. Keller for their helpful comments on this manuscript. Micrographs were taken with a Cambridge SEM operated by R. L. Oscarson. I appreciated the opportunity afforded me by the Deep Sea Drilling Project to participate as a member of the shipboard scientific staff of Leg 63.

\section{REFERENCES}

Akers, W. H., 1955. Some planktonic foraminifera of the American Gulf Coast and suggested correlations with the Caribbean Tertiary. J. Paleontol., 29:647-664.

Bandy, O. L., and Ingle, J. C., Jr., 1970. Neogene planktonic events and radiometric scale, California. Geol. Soc. Am. Spec. Pap. 124: 131-172.

Berggren, W. A., 1972. Cenozoic biostratigraphy and paleobiogeography of the North Atlantic. In Laughton, A. S., Berggren, W. A., et al., Init. Repts. DSDP, 12: Washington (U.S. Govt. Printing Office), 965-999.

Bermudez, P. J., 1961. Contribucion al estudio de las Globigerinidea de la region Caribe-Antillana (Paleoceno-Reciente). Bol. Geol. Publi. Espec. (Venez. Dir. Geol.) 3, (Cong. Geol. Venezolano, 3rd, Caracas 1959, Mem. 3), 1119-1393.

Blow, W. H., 1959. Age, correlation, and biostratigraphy of the upper Tocuyo (San Lorenzo) and Pozon Formations, eastern Falcon, Venezuela. Bulls. Am. Paleontol., 39:1-251.

1969. Late middle Eocene to Recent planktonic foraminiferal biostratigraphy. In Brönnimann, P., and Renz, H. H. (Eds.), Proc. First Planktonic Conference: Leiden (E. J. Brill), pp. 199-422.

Blow, W. H., and Banner, F. T., 1966. The morphology, taxonomy, and biostratigraphy of Globorotalia barisanensis LeRoy, Globorotalia fohsi Cushman and Ellisor, and related taxa. Micropaleontology, 12:286-302.

Bolli, H. M., 1954. Note on Globigerina concinna Reuss, 1850. Cushman Found. Foraminiferal Res. Contr., 5:1-3.

1957. Planktonic foraminifera from the Oligocene-Miocene Cipero and Lengua Formations of Trinidad, B.W.I. U.S. Nat. Mus. Bull., 215:97-124.

Bolli, H. M., and Bermudez, P. J., 1965. Zonation based on planktonic foraminifera of middle Miocene to Pliocene warm-water sediments. Asoc. Venez. Geol. Min. Pet. Bol. Inf., 8:119-149.

Brady, H. B., 1877. Supplementary note on the foraminifera of the chalk(?) of the New Britain Group. Geol. Mag. New Series Decade II, 4:534-536.

1879. Notes on some of the reticulation rhizopoda of the Challenger expedition. Q. J. Micros. Sci. (London), 19:20-26, 261-299, pls. 3-5, 8.

, 1882. Report on the foraminifera. In Tizard and Murray, Exploration of the Faröe Channel during the summer of 1880 in H.M.S. "Knight Errant," with subsidiary reports. Proc. R. Soc. Edinburgh, 11 (1880-1882):708-717.

1884. Report on the foraminifera dredged by H.M.S. Challenger during the years 1873-1876. Report on the Scientific Results of the Voyage of H.M.S. Challenger during the years 1873-1876: London, Zoology, 9, pt. 22, 814 p., 115 pls. (in Atlas).

Brönnimann, P., and Resig, J., 1971. A Neogene Globigerinacean biochronologic time-scale of the southwestern Pacific. In Winterer, E. L., Riedel, W. R., et al., Init. Repts. DSDP, 7, Pt. 2: Washington (U.S. Govt. Printing Office), 1235-1469.

Chapman, F., Parr, W. J., and Collins, A. C., 1934. Tertiary foraminifera of Victoria, Australia-The Balcombian deposits of Port Phillip, Pt. 3. Linn. Soc. London J., Zoology, 38:553-577.
Cushman, J. A., 1918. Some Pliocene and Miocene foraminifera of the coastal plain of the United States. U.S. Geol. Surv. Bull. 676:1-100.

Cushman, J. A., and Ellisor, A. C., 1939. New species of foraminifera from the Oligocene and Miocene. Cushman Found. Foraminiferal Res. Contr., 15:1-14.

Cushman, J. A., and Jarvis, P. W., 1936. Three new foraminifera from the Miocene, Bowden marl, of Jamaica. Cushman Found. Foraminiferal Res., Contr., 12:3-5.

Cushman, J. A., and Ponton, G. M., 1932. The foraminifera of the Upper, Middle, and part of the Lower Miocene of Florida. Fla. Geol. Surv. Bull., 9:7-147.

Cushman, J. A., and Stainforth, R. M., 1945. The foraminifera of the Cipero Marl Formation of Trinidad, British West Indies. Cushman Found. Foraminiferal Res. Spec. Publ., 14:1-75.

Deshayes, G. P., 1832. Encyclopedie methodique; histoire naturelle des vers (Vol. 2, Pt. 2, and Vol. 3): Paris (Mme. v. Agasse).

d'Orbigny, A., 1826. Tableau méthodique de la classe de Cephalopodes. Ann. Sci. Nat. de Paris, Ser. 1, 7:95-314, pls. 10-17 (fide Stainforth et al., 1975).

1839a. Foraminiferes. In Sagra, R. de la (Ed.), Histoire Physique, Politique et Naturelle de l'ile de Cuba: Paris (A. Bertrand) (fide Stainforth et al., 1975).

1839b. Foraminiferes des Iles Canaries. In Barker-Webb, and Berthelot (Eds.), Histoire Naturelle des Iles Canaries (Vol. 2, Pt. 2, Zool.): Paris (Bethune), 119-146, pls. 1-3 (fide Banner and Blow, 1960a).

Egger, J. G., 1893. Foraminiferen aus Meeresgrundproben, gelothet von 1874 vis 1876 von S. M. Sch. Gazelle. Königlichen Bayerischen Akademie der Wissenschaften, Mathematisch-Physikal- ischen Classe Abhandlungen, 18:193-458 (1-266), pls. 1-27.

Ehrenberg, C. G., 1861, Elemente des tiefen Meeresgrundes im Mexikanischen Golfstrome bei Florida; Uber die Tiefgrunde-Verhaltnisse des Oceans am Eingange der Davisstrasse und bei Island. Königlichen Preussische Akademie Wissenschaften Berlin, Monatsberichte, Berlin, pp. 222-240, 275-315, with map and chart.

Galloway, J. J., and Wissler, S. G., 1927. Pleistocene foraminifera from the Lomita quarry, Palos Verdes Hills, California. J. Paleontol., 1:35-87.

Haq, B., Yeats, R. S., Barron, J. A., et al., 1979. Eastern Pacific boundary currents. Geotimes, 24:30-31.

Hedberg, H. D., 1937. Foraminifera of the middle Tertiary Carapita Formation of northeastern Venezuela. J. Paleontol., 11:661-697.

Hofker, J., 1956. Foraminifera Dentata: Foraminifera of Santa Cruz and Thatch Island, Virginia-Archipelago West Indies. Copenhagen Univ. Zool. Mus. Spolia (Skrifter), 15:234.

Hornibrook, N. de B., 1958. New Zealand foraminifera: key species in stratigraphy-No. 6. New Zealand J. Geol. Geophys., 1:653676.

Ingle, J. C., Jr., 1973a. Neogene foraminifera from the northeastern Pacific Ocean, Leg 18, Deep Sea Drilling Project. In Kulm, L. D., von Huene, R., et al., Init. Repts. DSDP, 18: Washington (U.S. Govt. Printing Office), 517-567.

1973b. Summary comments on Neogene biostratigraphy, physical stratigraphy, and paleo-oceanography in the marginal northeastern Pacific Ocean. In Kulm, L. D., von Huene, R., et al., Init. Repts. DSDP, 18: Washington (U.S. Govt. Printing Office), 949-960.

Jenkins, D. G., 1960. Planktonic foraminifera from the Lakes Entrance oil shaft, Victoria, Australia. Micropaleontology, 6:345371.

1964. A new planktonic foraminiferal subspecies from the Australasian Lower Miocene. Micropaleontology, 10:72.

Keller, G., 1978a. Late Neogene biostratigraphy and paleoceanography of DSDP Site 310, Central North Pacific, and correlation with the Southwest Pacific. Mar. Micropaleontol., 3:97-119.

1978b. Late Neogene planktonic foraminiferal biostratigraphy and paleoceanography of the northeastern Pacific: evidence from DSDP Sites 173 and 310 at the North Pacific Front. $J$. Foraminiferal Res., 8:332-349.

1978c. Morphologic variation of Neogloboquadrina pachyderma (Ehrenberg) in sediments of the marginal and central north- 
east Pacific Ocean and paleoclimatic interpretation. J. Foraminiferal Res., 8:208-224.

Keller, G., and Poore, R. Z., 1980. Globigerinoides kennetti: A new late Miocene to earliest Pliocene planktonic Foraminifera from the Atlantic and Pacific Oceans. Micropaleontology, 26:189-192.

Kennett, J. P., 1966. The Globorotalia crassaformis bioseries in north Westland and Marlborough, New Zealand. Micropaleontology, $12: 235-245$

1973. Middle and late Cenozoic planktonic foraminiferal biostratigraphy of the southwest Pacific-DSDP Leg 21. In Burns, R. E., Andrews, J. E., et al., Init. Repts. DSDP, 21: Washington (U.S. Govt. Printing Office), 575-639.

LeRoy, L. W., 1939. Some small foraminifera, ostracoda, and otoliths from the Neogene ("Miocene') of the Tokan-Tapanoeli area, central Sumatra. Natuurwet. Tijdschr. Ned.-Indie, 99 (No. 6): 215-296, pls. 1-14 (fide Stainforth et al., 1975).

Lipps, J. H., 1964. Miocene planktonic Foraminifera from Newport Bay, California. Tulane Stud. Geol., 2:109-132.

Marks, P., Jr., 1951. A revision of the smaller Foraminifera from the Miocene of the Vienna Basin. Cushman Found. Foraminiferal Res. Contr., 2:33-73.

Natland, M. L., 1938. New species of foraminifera from off the west coast of North America and from the later Tertiary of the Los Angeles Basin. Univ. Calif. Scripps Inst. Oceanogr. Bull., Tech. Ser., 4:137-164.

Orr, W. N., and Zaitseff, J. B., 1971. A new planktonic foraminiferal species from the California Pliocene. J. Foraminiferal Res., 1:17-19.

Palmer, D. K., 1945. Notes on the foraminifera from Bowden, Jamaica. Bulls. Am. Paleontol., 29:5-82.

Parker, F. L., 1958. Eastern Mediterranean foraminifera. Swedish Deep-Sea Exped. Repts., 8:219-283.

, 1962. Planktonic foraminiferal sepcies in Pacific sediments. Micropaleontology, 8:219-254.

1967. Late Tertiary biostratigraphy (planktonic foraminifera) of tropical Indo-Pacific deep-sea cores. Bulls. Am. Paleontol., 52:115-208.

Parker, W. K., and Jones, T. R., 1865. On some foraminifera from the North Atlantic and Arctic oceans, including Davis Straits and
Baffin's Bay. Philos. Trans. R. Soc. London, 155:325-441, pls. 13-19 (fide Banner and Blow, 1960a).

Parker, W. K., Jones, T. R., and Brady, H. B., 1865. On the nomenclature of the foraminifera; Pt. 12 (misprinted as Pt. 10 continued-The species enumerated by d'Orbigny in the Annales des Sciences Naturelles, Vol. 7, 1826. Annual Magazine of Natural History, London, Ser. 3, 16:15-41, pls. 1-3 (fide Banner and Blow, 1960a)

Poag, C. W., and Valentine, P. C., 1976. Biostratigraphy and ecostratigraphy of the Pleistocene Basin Texas-Louisiana Continental Shelf Trans. Gulf Coast Assoc. Geol. Socs., 26:185-256.

Poore, R. Z., 1979. Oligocene through Quaternary planktonic foraminiferal biostratigraphy of the North Atlantic: DSDP Leg 49. In Luyendyk, B. P., Cann, J. R., et al., Init. Repts. DSDP, 49: Washington (U.S. Govt. Printing office), 447-518.

Poore, R. Z., and Berggren, W. A., 1975. Late Cenozoic planktonic foraminiferal biostratigraphy and paleoclimatology of HattonRockall Basin: DSDP Site 116. J. Foraminiferal Res., 5:270-293.

Quilty, P. G., 1976. Planktonic foraminifera DSDP Leg 34-Nazca Plate. In Yeats, R. S., Hart, S. R., et al., Init. Repts. DSDP, 34: Washington (U.S. Govt. Printing Office), 629-703. 1978. Globorotalia galapagosensis replacement name for Globorotalia akersi Quilty, 1976 not Globorotalia akersi Snyder, 1975. Micropaleontology, 24:332.

Salvatorini, G., 1966. Alcune nuove specie di foraminiferi del Miocene superiore della Toscana Marittima. Atti Soc. Toscana Sci. Nat. Pisa, Mem., Ser. A, 73:3-13.

Schwager, Conrad, 1866. Fossile Foraminiferen von Kar Nikobar. Novara Exped. 1857-1859 (Vol. 2): Wien (Geol. Theil), 187-268.

Takayanagi, Y., and Saito, T., 1962. Planktonic foraminifera from the Nobori Formation, Shikoku, Japan. Tohoku Univ. Sci. Rep. Ser. 2 (Geology), Spec. Vol. No. 5:67-105.

Todd, R., 1957. Smaller foraminifera. U.S. Geol. Surv. Prof. Paper, 280-H:265-320.

Todd, R., Cloud, P. E., Jr., Low, D., et al., 1954. Probable occurrence of Oligocene on Saipan. Am. J. Sci., 252:673-682.

Walters, R., 1965. The Globorotalia zealandica and G. miozea lineages. New Zealand J. Geol. Geophys., 8:109-127. 


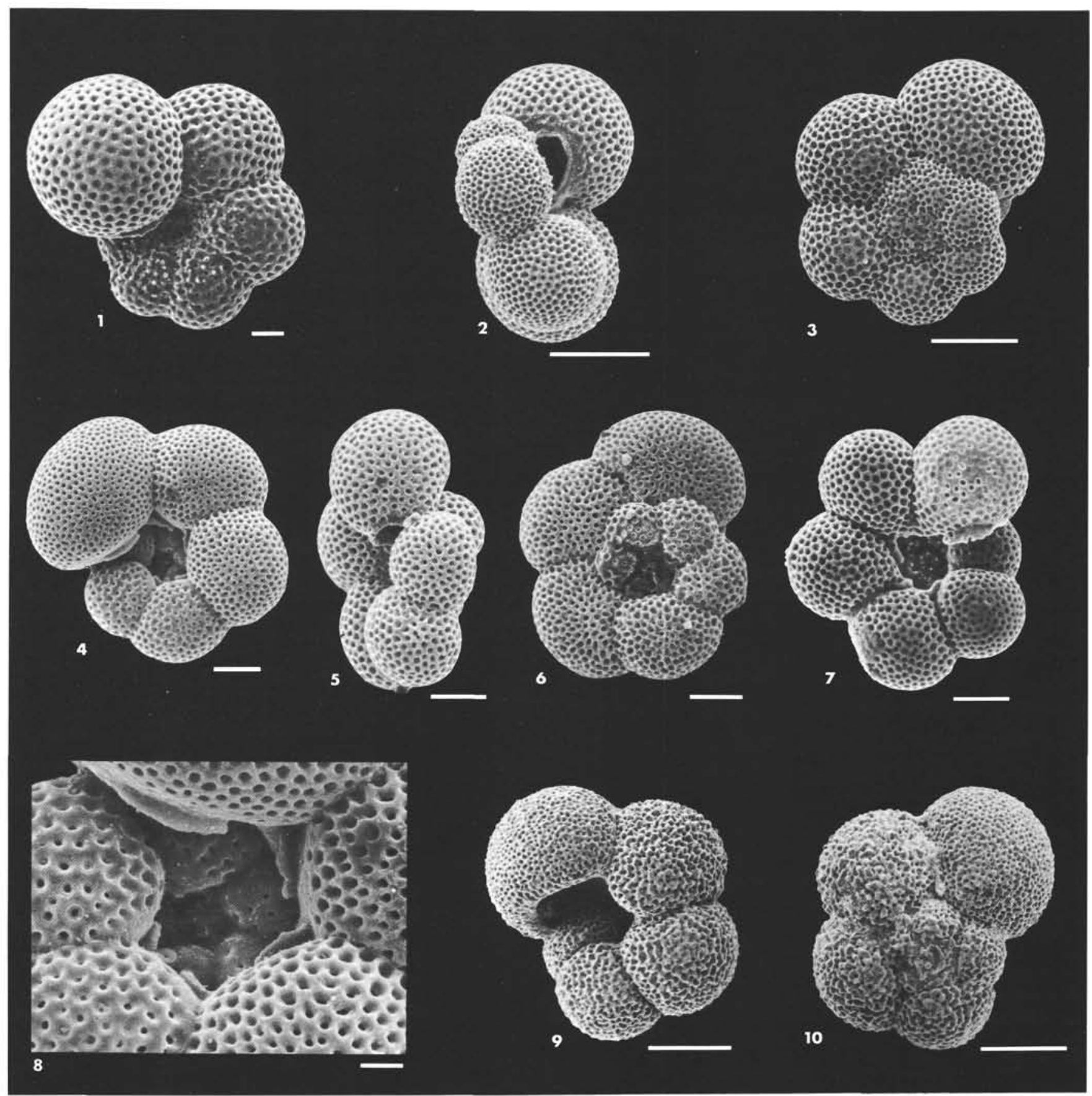

Plate 1. 1-3. Globorotaloides hexagona (Natland). Sample 470-17,CC. (1) Umbilical view, scale bar $=30 \mu \mathrm{m}$. (2) Side view, scale bar $=100 \mu \mathrm{m}$. (3) Spiral view, scale bar $=100 \mu \mathrm{m}$. 4-8. Globorotaloides trema Lipps. Sample 470-17,CC. (4) Umbilical view, scale bar $=30 \mu \mathrm{m}$. (5) Side view, scale bar $=30 \mu \mathrm{m}$. (6) Spiral view, scale bar $=30 \mu \mathrm{m}$. (7) Umbilical view, scale bar $=30 \mu \mathrm{m}$. (8) Enlarged umbilical view of Fig. 4, scale bar $=10 \mu \mathrm{m} .9,10$. Globigerina pseudociperoensis Blow. Sample 468-7,CC. (9) Umbilical view, scale bar $=100 \mu \mathrm{m}$. (10) Spiral view of Fig. 9, scale bar $=100 \mu \mathrm{m}$. 

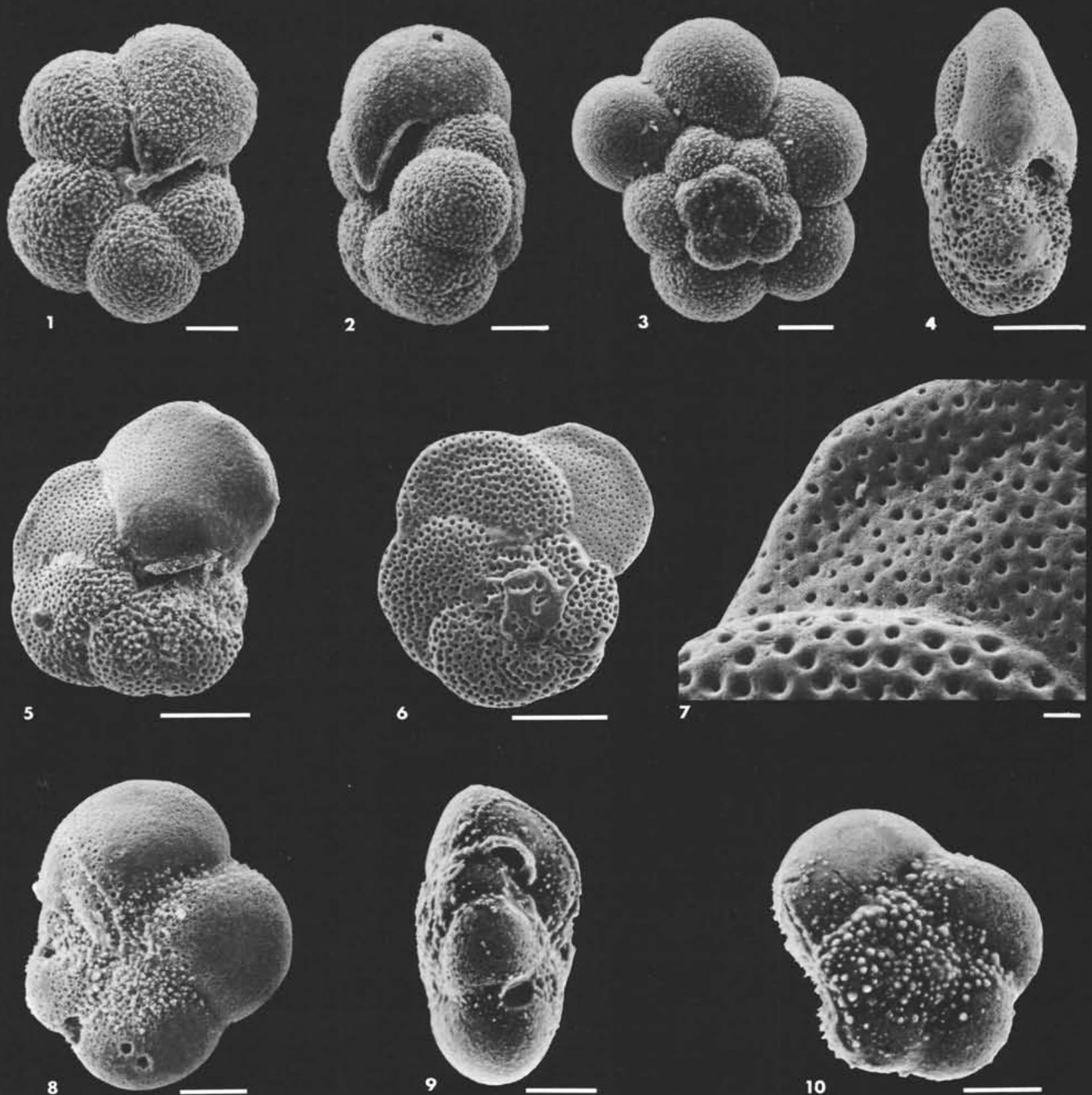

8

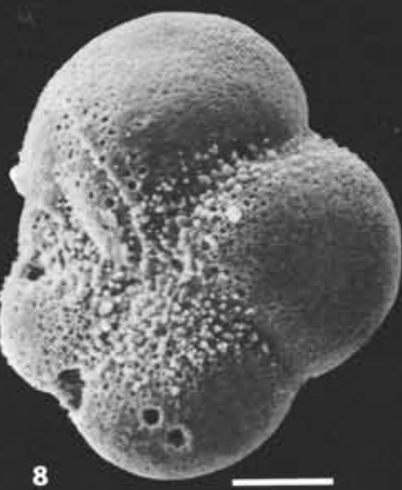

10

Plate 2. 1-3. Globorotalia minutissima Bolli. Sample 470-17,CC. (1) Umbilical view, scale bar $=30 \mu \mathrm{m}$. (2) Side view, scale bar $=30 \mu \mathrm{m}$. (3) Spiral view, scale bar $=30 \mu \mathrm{m}$. 4-7. Globorotalia peripheroacuta Blow and Banner. (4) Side view. Sample 470-17-2, 30-32 cm. Scale bar $=100 \mu \mathrm{m}$. (5) Umbilical view. Sample 470-17-3, 30-32 cm. Scale bar $=100 \mu \mathrm{m}$. (6) Spiral view. Sample 470-17-2, 30-32 cm. Scale bar $=100 \mu \mathrm{m}$. (7) Enlargement of Fig. 6, scale bar $=10 \mu \mathrm{m} .8-10$. Globorotalia galapagosensis Quilty. Sample 470-17,CC. (8) Umbilical view, scale bar $=30$ $\mu \mathrm{m}$. (9) Side view of Fig. 8 , scale bar $=30 \mu \mathrm{m}$. (10) Spiral view, scale bar $=30 \mu \mathrm{m}$. 


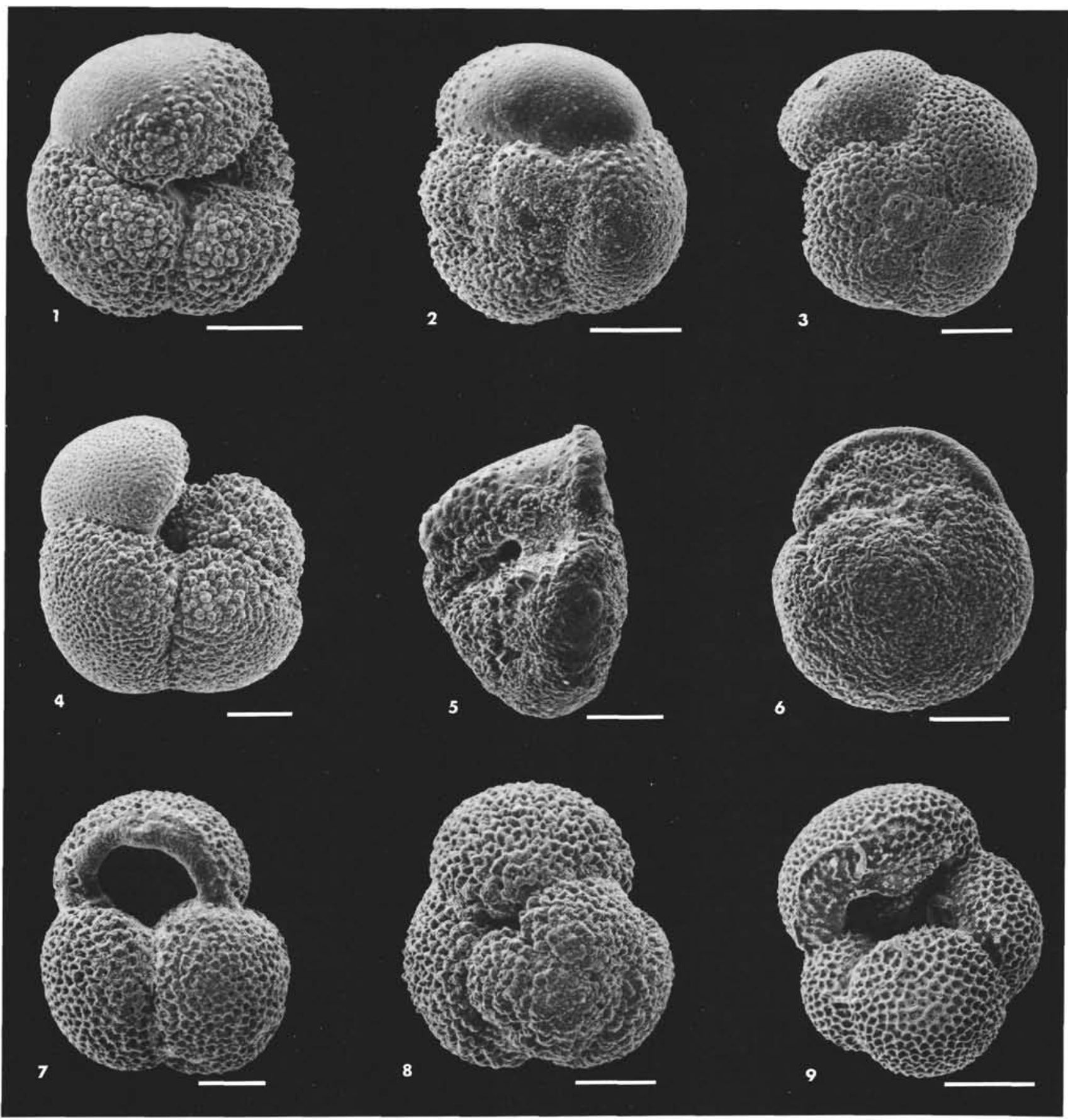

Plate 3. 1, 2. Globorotalia inflata (d'Orbigny). Sample 468B-1-3, 80-82 cm. (1) Umbilical view, scale bar $=100 \mu \mathrm{m}$. (2) Spiral view of Fig. 1, scale bar $=100 \mu \mathrm{m} .3,4$. Globorotalia puncticulata (Deshayes). Sample 468B-1-3, 80-82 cm. (3) Spiral view, scale bar $=100 \mu \mathrm{m}$. (4) Umbilical view, scale bar $=100 \mu \mathrm{m}$. 5, 6. Globorotalia conomiozea Kennett. Sample 468B-1,CC. (5) Side view, scale bar $=100 \mu \mathrm{m}$. (6) Spiral view, scale bar $=$ $100 \mu \mathrm{m} .7,8$. Globigerinoides kennetti Keller and Poore. Sample 470A-5,CC. (7) Umbilical view, scale bar $=100 \mu \mathrm{m}$. (8) Spiral view, scale bar $=100 \mu \mathrm{m}$. 9. Globoquadrina baroemoenensis (LeRoy). Sample 470-16-3, 20-22 cm. Umbilical view, scale bar $=100 \mu \mathrm{m}$. 


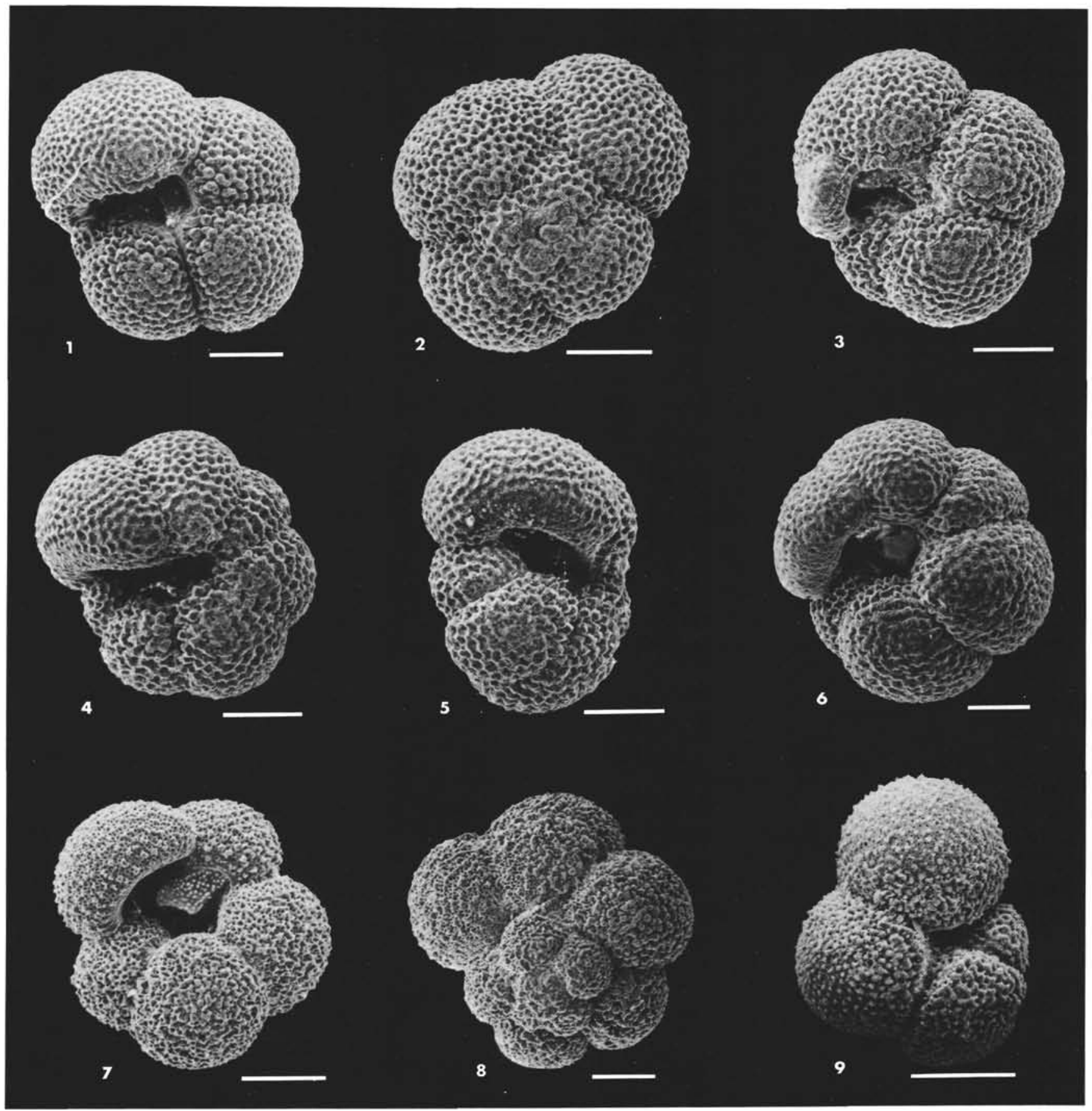

Plate 4. 1-3. Neogloboquadrina atlantica (Berggren). Sample 467-26,CC. (1) Umbilical view, scale bar $=100 \mu \mathrm{m}$. (2) Spiral view, scale bar $=100$ $\mu \mathrm{m}$. (3) Umbilical view, scale bar $=100 \mu \mathrm{m}$. 4, 5. Neogloboquadrina humerosa (Takayanagi and Saito). Sample 468A-1,CC. (4) Umbilical view, scale bar $=100 \mu \mathrm{m}$. (5) Side view of Fig. 4, scale bar $=100 \mu \mathrm{m}$. 6. Neogloboquadrina dutertrei (d'Orbigny). Sample 468-1-1, 3-5 cm. Umbilical view, scale bar $=100 \mu \mathrm{m}$. 7, 8. Globigerina umbilicata Orr and Zaitzeff. (7) Umbilical view. Sample 467-26,CC. Scale bar $=100 \mu \mathrm{m}$. (8) Spiral view. Sample 467-25-4, 60-62 cm. Scale bar $=100 \mu \mathrm{m}$. 9. Globigerina incisa (Bronnimann and Resig). Sample 470-7-2, 60-62 cm. Umbilical view, scale bar $=100 \mu \mathrm{m}$. 


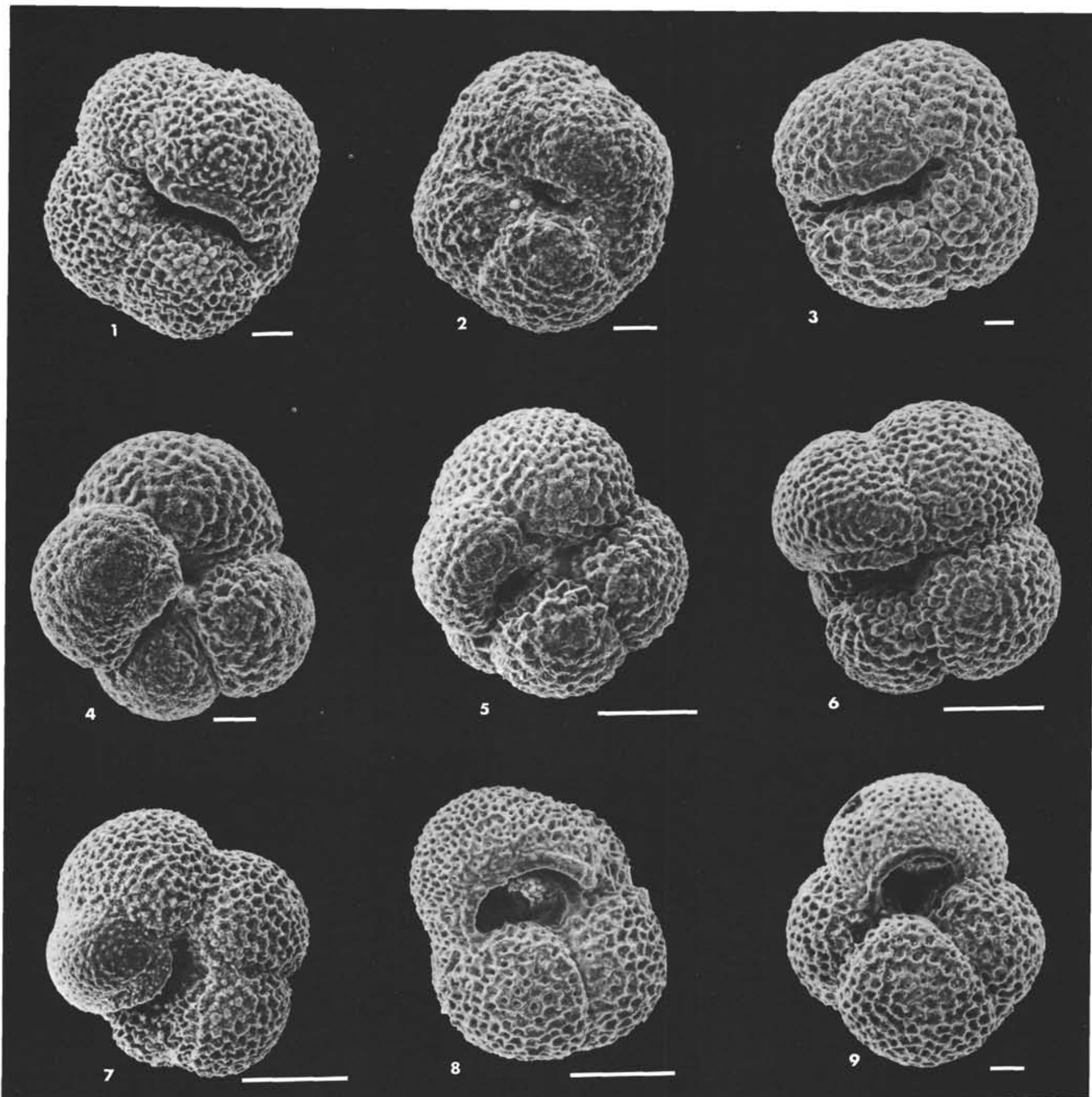

Plate 5. 1-3. Neogloboquadrina pachyderma (Ehrenberg) s.s. (1) Umbilical view, Sample 468A-1-3, 90-92 cm. Scale bar $=30 \mu \mathrm{m}$. (2) Umbilical view. Sample 467-11,CC. Scale bar $=30 \mu \mathrm{m}$. (3) Umbilical view. Sample 468A-1-3, 90-92 cm. Scale bar $=30 \mu \mathrm{m}$. 4-7. Neogloboquadrina pachyderma (Ehrenberg) s.l. (4) Umbilical view. Sample 467-26,CC. Scale bar $=30 \mu \mathrm{m}$. (5) Umbilical view. Sample 468A-3-2, 123-125 cm. Scale bar $=100 \mu \mathrm{m}$. (6) Umbilical view. Sample 467-26,CC. Scale bar $=100 \mu \mathrm{m}$. (7) Umbilical view. Sample 467-26,CC. Scale bar $=100$ $\mu \mathrm{m}$. 8. Globigerina nepenthes Todd. Sample 470-15-4, 60-62 cm. Umbilical view, scale bar $=100 \mu \mathrm{m}$. 9. Globigerina druryi Akers. Sample $470-15-4,60-62 \mathrm{~cm}$. Umbilical view, scale bar $=30 \mu \mathrm{m}$. 